\title{
Improving the Stability of EGFR Inhibitor Cobalt(III) Prodrugs
}

\author{
Marlene Mathuber, Hemma Schueffl, Orsolya Dömötör, Claudia Karnthaler, Éva A. Enyedy, \\ Petra Heffeter, Bernhard K. Keppler, and Christian R. Kowol*
}

Cite This: Inorg. Chem. 2020, 59, 17794-17810

Read Online



ABSTRACT: Although tyrosine kinase inhibitors (TKIs) have revolutionized cancer therapy in the past two decades, severe drawbacks such as strong adverse effects and drug resistance limit their clinical application. Prodrugs represent a valuable approach to overcoming these disadvantages by administration of an inactive drug with tumor-specific activation. We have recently shown that hypoxic prodrug activation is a promising strategy for a cobalt(III) complex bearing a TKI of the epidermal growth factor receptor (EGFR). The aim of this study was the optimization of the physicochemical properties and enhancement of the stability of this compound class. Therefore, we synthesized a series of novel derivatives to investigate the influence of the electron-donating properties of methyl substituents at the metal-chelating moiety of the EGFR inhibitor and/or the ancillary acetylacetonate (acac) ligand. To understand the effect of the different

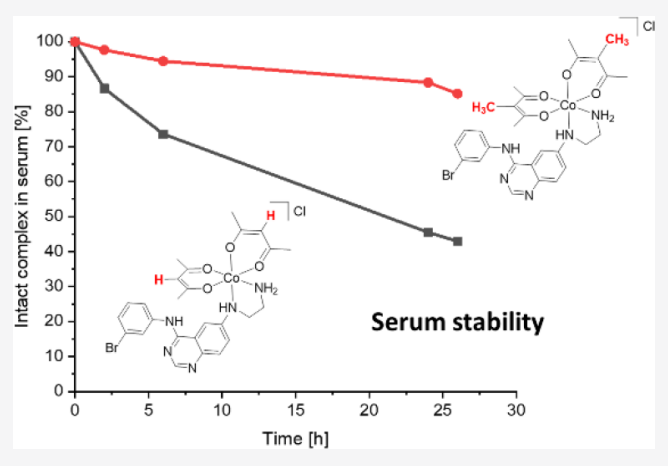
methylations on the redox properties, the newly synthesized complexes were analyzed by cyclic voltammetry and their behavior was studied in the presence of natural low-molecular weight reducing agents. Furthermore, it was proven that reduction to cobalt(II) resulted in a lower stability of the complexes and subsequent release of the coordinated TKI ligand. Moreover, the stability of the cobalt(III) prodrugs was investigated in blood serum as well as in cell culture by diverse cell and molecular biological methods. These analyses revealed that the complexes bearing the methylated acac ligand are characterized by distinctly enhanced stability. Finally, the cytotoxic activity of all new compounds was tested in cell culture under normoxic and various hypoxic conditions, and their prodrug nature could be correlated convincingly with the stability data. In summary, the performed chemical modifications resulted in new cobalt(III) prodrugs with strongly improved stabilities together with retained hypoxia-activatable properties.

\section{INTRODUCTION}

The epidermal growth factor receptor (EGFR) belongs to the family of receptor tyrosine kinases, a group of proteins that are responsible for numerous signal transduction processes in the human body (e.g., cell growth, differentiation, and metabolism). ${ }^{1}$ Hence, an overexpression of the EGFR can be observed in various types of solid tumors, including those of lung, head and neck, ovary, breast, and colon. ${ }^{2,3}$ Especially in non-small-cell lung cancer (NSCLC), which is still one of the leading causes of cancer-related deaths worldwide, the EGFR is overexpressed in at least $50 \%$ of the patients. ${ }^{4}$ Moreover, "activating mutations" of the EGFR protein have been observed in $\leq 20 \%$ of the patients, which results in a permanent activation of this signaling pathway. ${ }^{5}$ As such, cancer cells are highly dependent on the respective growth signals and the development of EGFR inhibitors as targeted therapeutics has been of great interest over the past two decades. As a result of this intensive research, several small-molecule or antibody inhibitors targeting the EGFR have been clinically developed mainly for NSCLC treatment. ${ }^{6}$ The mode of action of low-molecular weight EGFR tyrosine kinase inhibitors (TKIs) is the (ir)reversible binding into the ATP-binding pocket, which hampers the activation of the downstream signaling [e.g., phosphorylation of extracellular signal-regulated kinases (ERKs)]. ${ }^{7}$ The clinically approved EGFR TKIs comprise gefitinib (Iressa, 2003), erlotinib (Tarceva, 2004), afatinib (Gilotrif, 2013), and osimertinib (Tagrisso, 2017), which are all used for the treatment of NSCLC. ${ }^{6}$ In addition, erlotinib (in combination with gemcitabine) is approved for advanced and metastatic pancreatic cancer. ${ }^{8}$

Unfortunately, besides the rapid development of drug resistance, EGFR- targeting TKIs in clinical application found their limitations in insufficient tumor accumulation and induction of side effects such as severe papulopustular skin rashes, gastrointestinal-related adverse events, or fatigue. ${ }^{9}$ It is noteworthy that the intensity of these observed "on-target" adverse effects directly correlates with therapy response. ${ }^{0,11}$ Thus, patients suffering from the most severe side effects (and consequently most likely to have to discontinue therapy) are the

Received: October 16, 2020

Published: November 21, 2020 


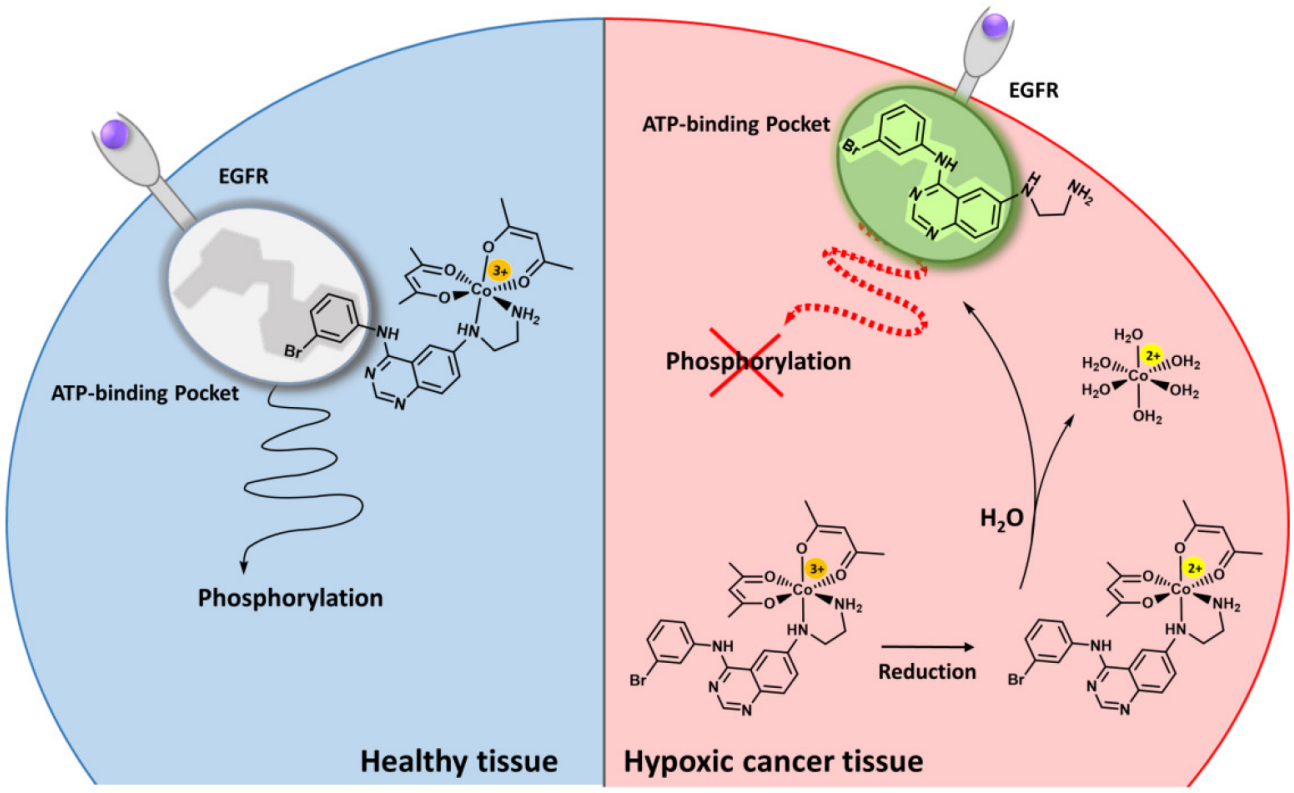

Figure 1. Proposed mechanism of the hypoxia-activated cobalt(III) prodrug system. In healthy tissue (left), the cobalt(III) complex is too bulky to fit into the ATP-binding pocket of the EGFR and is therefore biologically inactive. In the hypoxic environment of the tumor (right) an irreversible reduction takes place. This results in the release of the TKI ligand with formation of cobalt(II) species $\left\{\left[\mathrm{Co}\left(\mathrm{H}_{2} \mathrm{O}\right)_{6}\right]^{2+}\right.$ and mixed acac/ $\mathrm{H}_{2} \mathrm{O}$ complexes $\}$ and subsequent inhibition of EGFR-downstream signaling.

Scheme 1. Chemical Structures of EGFR Inhibitor Ligands $\mathrm{L}$ and $\mathrm{MeL}$ as well as Cobalt(III) Complexes $\mathrm{Co}(\text { acac })_{2} \mathrm{~L}^{+}$, $\mathrm{Co}(\mathrm{Meacac}){ }_{2} \mathrm{~L}^{+}, \mathrm{Co}(\mathrm{acac})_{2} \mathrm{MeL}^{+}$, and $\mathrm{Co}(\mathrm{Meacac})_{2} \mathrm{MeL}^{+}$<smiles>NCCNc1ccc2ncnc(Nc3cccc(Br)c3)c2c1</smiles>

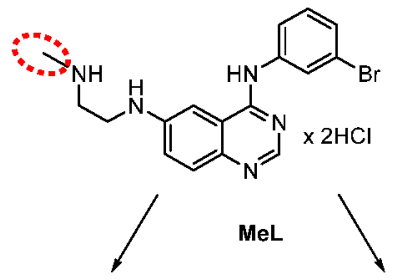<smiles>C=C(C)C=C(C)OC(C=C(C)C)(OC(C)=O)OC1(Nc2ccc3ncnc(Nc4cccc(Br)c4)c3c2)NCCN1</smiles>

$\mathrm{Co}(\operatorname{acac})_{2} \mathrm{~L}^{+}$

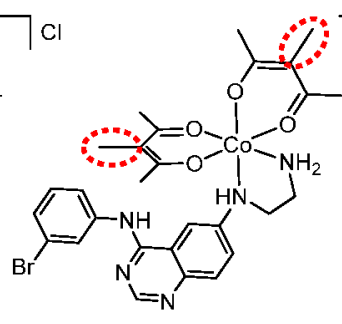

Co(Meacac) ${ }_{2} \mathrm{~L}^{+}$

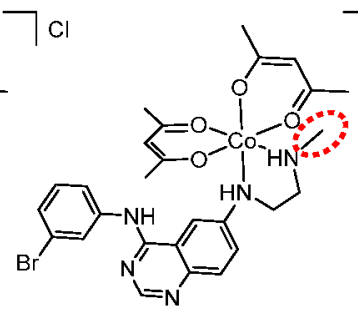

$\mathrm{Co}(\text { acac })_{2} \mathrm{MeL}^{+}$

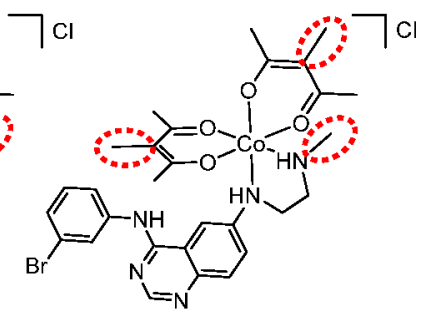

$\mathrm{Co}(\text { Meacac })_{2} \mathrm{MeL}^{+}$ ones who would benefit most from EGFR inhibitor treatment. ${ }^{10}$ Because adverse effects usually arise from a lack of tumor specificity, the use of prodrug systems is a promising approach to overcoming these drawbacks. Anticancer prodrugs are defined as inactivated (nontoxic) derivatives of drugs, which ideally release their active moiety at the desired site of action (e.g., tumors) by specific activation. ${ }^{12}$ Cancer tissue distinguishes itself from the healthy surroundings in different ways. ${ }^{13}$ One well-researched example is the occurrence of hypoxic areas in solid tumors caused by insufficient blood supply based on their uncontrolled and fast growth. ${ }^{14,15}$ To exploit these tumor characteristics, several substance classes of hypoxia-activated prodrugs such as nitroaromatics, quinones, transition metal complexes [especially cobalt(III) systems], and aromatic $N$ oxides have been developed. Some of these compounds [e.g., tirapazamine, TH-302 (evofosfamide), and apaziquone] have already been investigated even in clinical phase III studies; however, no representative has reached clinical approval so far. ${ }^{16}$ Notably, for the large class of existing TKIs, only a few attempts have been made to convert them into prodrugs that can be activated under hypoxic conditions. ${ }^{17-20}$

With regard to metal-based drugs, cobalt complexes can be used as attractive prodrug systems due to their adjustable redox potential and well-established coordination chemistry. ${ }^{21-23}$ Most important for this prodrug system is the kinetic inertness of octahedral cobalt(III) complexes, whereas (after a oneelectron reduction) the cobalt(II) state is labile with fast ligand exchange processes. ${ }^{21,24}$ Applying this mechanism to the hypoxic environment of a tumor, the inactive prodrug will undergo an irreversible reduction in the hypoxic tissue with 

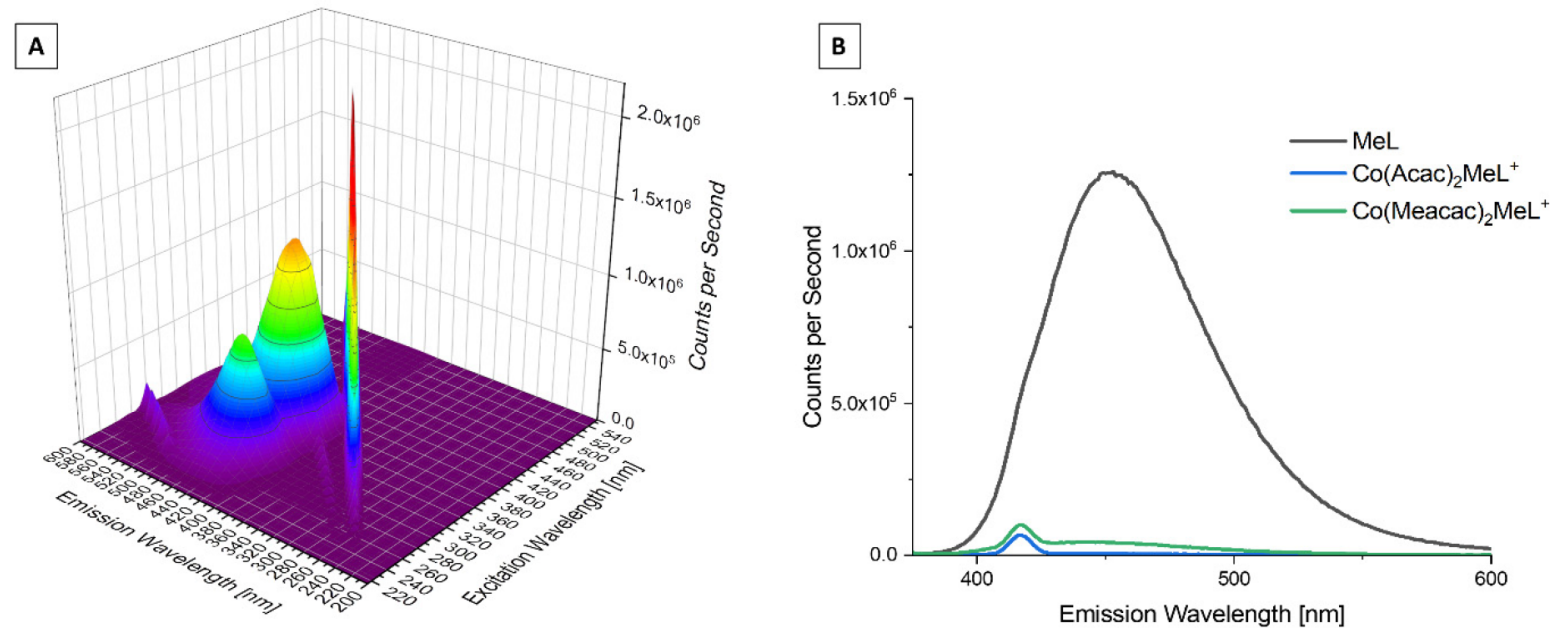

Figure 2. (A) 3D full excitation-emission landscape of MeL (Rayleigh scattering of first and second order appears as diagonal ridges). (B) Fluorescence emission spectra at a $\lambda_{\text {ex }}$ of $365 \mathrm{~nm}$ of MeL, Co( acac) ${ }_{2} \mathrm{MeL}^{+}$, and $\mathbf{C o}(\mathbf{M e a c a c})_{2} \mathrm{MeL}^{+}$(the peaks at $420 \mathrm{~nm}$ are caused by Raman scattering $\left.{ }^{28}\right)$. All measurements were performed in PBS at pH $7.40\left(30 \mu \mathrm{M}\right.$ ligand, $30 \mu \mathrm{M}$ complex, and $\left.25.0^{\circ} \mathrm{C}\right)$.

subsequent ligand release. In contrast, in healthy tissues the complex is stable, preventing the ligand from exerting its biological activity. It is noteworthy that Ware et al. already showed that in the case of monodentate aziridine ligands, the cobalt(II) complexes do not have sufficient stability under normoxic conditions. Consequently, bidentate chelating ligands are preferred for the design of novel prodrug complexes. ${ }^{21} \mathrm{We}$ have recently successfully developed the first cobalt(III)-based prodrug $\left[\mathbf{C o}(\mathbf{a c a c}){ }_{2} \mathbf{L}^{+}\right]$for a new EGFR inhibitor (denoted as L) ${ }^{17}$ (Figure 1). Notably, the potential of this new compound class could be observed in several cancer cell models in vitro and demonstrated encouraging results in vivo using xenograft tumor models in mice. However, subsequent investigations showed only moderate stability of the complex toward reduction in blood serum. Consequently, the aim of this study was to further improve this substance class by decreasing the cobalt redox potential leading to higher stability. Therefore, we synthesized several novel derivatives, evaluated their properties (electrochemical potential, interaction with natural reducing agents, and serum stability), and correlated them with their cytotoxic activity against cancer cell lines.

\section{RESULTS AND DISCUSSION}

Synthesis and Characterization. To design an EGFR inhibitor that can coordinate to cobalt(III), we used in our previous study the typical quinazoline ring of most approved EGFR inhibitors but modified the 6 position by introducing an ethylenediamine ("en") type metal-binding moiety [L (Scheme 1) $].{ }^{17}$ Reaction with $\mathrm{Na}\left[\mathrm{Co}(\mathrm{acac})_{2}\left(\mathrm{NO}_{2}\right)_{2}\right]($ acac $=$ acetylacetonate) yielded the cobalt(III) EGFR inhibitor ternary complex $\mathbf{C o}(\text { acac })_{2} \mathbf{L}^{+}$. To develop derivatives with lower redox potentials and consequently higher expected (blood plasma) stabilities, we followed two strategies: (1) introduction of an electron-donating methyl group at the "en" moiety (MeL) and/ or (2) using methylacetylacetone (Meacac) instead of acac as the ancillary ligand.

MeL was synthesized using $N$-(3-bromophenyl)quinazoline4,6-diamine, $\mathrm{N}$-Boc-(methylamino)-acetaldehyde, and sodium cyanoborohydride. After deprotection with $\mathrm{HCl}, \mathrm{MeL}$ could be obtained in $\sim 80 \%$ yield as a dihydrochloride salt. The cobalt(III) complexes were synthesized by reaction of $\mathrm{Na}$ [Co$\left.(\text { acac })_{2}\left(\mathrm{NO}_{2}\right)_{2}\right]$ or $\mathrm{Na}\left[\mathrm{Co}(\mathrm{Meacac})_{2}\left(\mathrm{NO}_{2}\right)_{2}\right]$ with $\mathrm{L}$ or $\mathrm{MeL}$ in a water/methanol mixture in the presence of activated charcoal following a procedure described by Denny et al. ${ }^{21}$ (Scheme 1). Finally, addition of brine to the reaction mixture resulted in the precipitation of the complex as a chloride salt. Afterward, the crude product was purified by reversed-phase high-performance liquid chromatography (HPLC) (without addition of acids to the eluent to avoid a counter ion exchange). The novel compounds were characterized by mass spectrometry, ${ }^{1} \mathrm{H}$ and ${ }^{13} \mathrm{C}$ one- and two-dimensional nuclear magnetic resonance (NMR) spectroscopy, and elemental analysis.

Of note are especially the NMR spectra of the cobalt(III) complexes. In the case of $\mathbf{C o}(\text { acac })_{2} \mathbf{L}^{+17}$ and $\mathbf{C o}$ (Meacac) ${ }_{2} \mathbf{L}^{+}$, two independent signal sets can be observed, belonging to two pairs of diastereomers (Figure S1 and ref 17). The two stereogenic centers originate from the propeller chirality of the complex itself and the anilinic $\mathrm{NH}$ group. In the case of methylated ligand $\mathbf{M e L}$, an additional stereocenter is formed, ${ }^{25,26}$ resulting in four sets of signals for complexes Co(acac) ${ }_{2} \mathrm{MeL}^{+}$and $\mathbf{C o}\left(\right.$ Meacac) ${ }_{2} \mathbf{M e L}^{+}$(Figures S2 and S3). The presence of these isomers can be easily seen in the ${ }^{1} \mathrm{H}$ NMR spectra, where depending on the complex, two or four separated singlets of the NH group appear (Figure S4). However, especially in the aromatic area and within the "en" bridge the protons tend to overlap. Therefore, an exact assignment of all NMR signals could not be achieved (see Experimental Section). Isolation of pure diastereomers by reversed-phase HPLC was not possible, because the product peaks could not be separated (also a change in the gradient or solvent and the addition of formic acid did not result in sufficient separation).

Fluorescence Properties. In our previous work, ${ }^{17}$ we showed that EGFR inhibitor ligand $\mathbf{L}$ possesses distinct fluorescence properties with an emission maximum at $455 \mathrm{~nm}$ upon irradiation at $370 \mathrm{~nm}$. This fluorescence is completely quenched by coordination to the cobalt(III) ion $\left[\mathrm{Co}(\text { acac })_{2} \mathrm{~L}^{+}\right.$. Therefore, we also examined the fluorescence of $\mathrm{MeL}$ and the novel complexes in phosphate-buffered saline (PBS) at pH 7.40. The three-dimensional (3D) spectrum of MeL (Figure 2A) is similar in intensity and maxima $\left(\lambda_{\mathrm{em}}=455 \mathrm{~nm}\right.$, and $\lambda_{\mathrm{ex}}=365$ $\mathrm{nm}$ ) compared to $\mathbf{L}$. In agreement to our previous data, the fluorescence of all cobalt(III) complexes is negligible, most probably due to the metal center, resulting in extremely fast intersystem crossing rates in the excited state ${ }^{27}$ [Figure $2 \mathrm{~B}$ for 
$\mathrm{Co}$ (acac) ${ }_{2} \mathrm{MeL}^{+}$and $\left.\mathrm{Co}(\mathrm{Meacac}){ }_{2} \mathrm{MeL}^{+}\right]$. Therefore, we could exploit the fluorescence properties for stability studies of the complexes.

Lipophilicity. The first physicochemical property we investigated was the lipophilicity of the complexes, because it is a critical parameter for passing biological membranes. Distribution coefficients $\left(D_{7.4}\right)$ presented in Table 1 were determined by the traditional shake-flask method in an $n$-octanol/buffered aqueous solution at physiological $\mathrm{pH}$. All compounds containing an EGFR inhibitor ligand ( $\mathrm{L}$ or $\mathbf{M e L}$ ) show highly lipophilic character, despite the positive charge of the complexes. As expected, the methylated compounds are more lipophilic than $\mathbf{C o}(\mathbf{a c a c})_{2} \mathbf{L}^{+}$(Table 1). However, all complexes still show good water solubility. The active EGFR inhibitor ligand $\mathbf{L}$ itself proved to be highly lipophilic $\left(\log \mathrm{D}_{7.40}=\right.$ 1.86). ${ }^{29}$ Therefore, the lipophilic character of the complexes is mainly based on the coordinating EGFR inhibitor ligand and just slightly modulated by the attachment of the cobalt(methyl)acetylacetonato fragment [the simple model complex $\mathrm{Co}$ (acac) ${ }_{2} \mathrm{en}^{+}$is very hydrophilic with a $\log \mathrm{D}_{7.40}$ value of -1.86]. The highly lipophilic character of the complexes apparently contradicts the relatively good water solubility (0.5-1.0 mM in water or PBS). Variation of the composition of the aqueous phase in the case of $\mathbf{C o}(\mathbf{a c a c})_{2} \mathrm{~L}^{+}$revealed a strong dependence of the distribution coefficient on the ion content of the aqueous solution (see footnote of Table 1). This phenomenon refers to ion pair formation taking place between the single positively charged complex and anions like $\mathrm{Cl}^{-}$and $\mathrm{H}_{2} \mathrm{PO}_{4}^{-}$present in the buffer system. Distribution coefficients determined in $20 \mathrm{mM}$ phosphate and $0.1 \mathrm{M} \mathrm{KCl}$ probably represent best the lipophilicity of the complexes under physiological conditions.

These results are in line with HPLC measurements, where the retention time of the complexes increases with the number of methyl substituents resulting in the following order: Co$(\text { acac })_{2} \mathrm{~L}^{+}<\mathrm{Co}(\text { acac })_{2} \mathrm{MeL}^{+}<\mathrm{Co}(\text { Meacac })_{2} \mathrm{~L}^{+}<$ $\mathrm{Co}(\text { Meacac })_{2} \mathrm{MeL}^{+}$.

Cyclic Voltammetry. As the reduction process is crucial for the activation of cobalt(III)-based prodrug systems, the redox properties of the complexes were investigated to elucidate the effects of ligand methylation at different positions. Cyclic voltammetry measurements were performed in aqueous solution at $\mathrm{pH} 7.40(10 \mathrm{mM}$ phosphate buffer with $0.1 \mathrm{M}$ $\mathrm{KCl}$ ). The voltammograms at a scan speed of $30 \mathrm{mV} / \mathrm{s}$ showed a single irreversible cathodic peak in the range of $4-120 \mathrm{mV}$ versus the normal hydrogen electrode (NHE), which can be assigned to the reduction of cobalt(III) to cobalt(II) (Figure 3).

Table 1. Distribution Coefficients $\left(D_{7.40}\right)$ of the Complexes at $\mathrm{pH} 7.40\left[T=25.0^{\circ} \mathrm{C}\right.$, and $\left.I=0.1 \mathrm{M}(\mathrm{KCl})\right]$

\begin{tabular}{lc}
\multicolumn{1}{c}{ complex } & $\log D_{7.40}$ \\
$\mathrm{Co}(\mathrm{acac})_{2} \mathrm{~L}^{+a}$ & $1.59 \pm 0.06$ \\
$\mathrm{Co}(\mathrm{Meacac})_{2} \mathrm{~L}^{+}$ & $2.24 \pm 0.04$ \\
$\mathrm{Co}(\text { acac })_{2} \mathrm{MeL}^{+}$ & $2.05 \pm 0.17$ \\
$\mathrm{Co}(\mathrm{Meacac})_{2} \mathrm{MeL}^{+}$ & $>2.7$ \\
$\mathrm{Co}(\mathrm{acac})_{2} \mathbf{e n}^{+}$ & $-1.86 \pm 0.05$ \\
$\mathrm{~L}$ & $1.86 \pm 0.03^{29}$
\end{tabular}

${ }^{a}$ Distribution coefficients measured under different conditions: $\log D$ $=-0.55 \pm 0.01$ (water, $\mathrm{pH} \sim 6.5$ ), $-0.09 \pm 0.03[20 \mathrm{mM}$ phosphate buffer ( $\mathrm{pH} 7.40)]$, and $2.22 \pm 0.03$ [20 $\mathrm{mM}$ phosphate buffer and $0.58 \mathrm{M} \mathrm{KCl}(\mathrm{pH} 7.40)]$.
Also, at a much higher scan speed of $1000 \mathrm{mV} / \mathrm{s}$, the redox processes were still completely irreversible (Figure S5).

Compared to reference compound $\mathrm{Co}(\mathrm{acac}){ }_{2} \mathrm{~L}^{+}$with a cathodic peak at $62 \mathrm{mV}$ versus NHE, the methylation of the acac ligand $\mathbf{C o}($ Meacac $){ }_{2} \mathbf{L}^{+}$resulted in the desired lower cathodic peak potential at $4 \mathrm{mV}$ versus NHE. This trend is also in agreement with literature data of cobalt(III) prodrug systems containing nitrogen mustard ligands. ${ }^{21}$ In contrast to the expectations, methylation of the "en" moiety of the EGFR inhibitor ligand $\mathrm{Co}(\mathrm{Meacac}){ }_{2} \mathrm{MeL}^{+}$did not further decrease the reduction potential but resulted in a slightly higher cathodic potential (17 mV vs NHE). Analogously, Co(acac) ${ }_{2} \mathbf{M e L}^{+}$also showed an increased potential (120 mV vs NHE) compared to that of $\mathrm{Co}(\mathrm{acac}){ }_{2} \mathrm{~L}^{+}(62 \mathrm{mV}$ vs $\mathrm{NHE})$.

Notably, the reduction potential of reference compound $\mathrm{Co}(\mathrm{acac}){ }_{2} \mathrm{en}^{+}$was distinctly lower with a value of $-141 \mathrm{mV}$ versus NHE even compared to the most promising representative of the EGFR inhibitor-containing complexes, Co(Meacac $)_{2} \mathrm{~L}^{+}$, at $4 \mathrm{mV}$ versus NHE. To verify that the adjacent aromatic moiety of the quinazoline is responsible for this shift and that methylation of the "en" moiety indeed increases the redox potential, additional model complexes were synthesized (Figure 4): (1) $\mathbf{C o}(\mathbf{a c a c}){ }_{2} \mathbf{P h E n}^{+}$to determine the influence of the phenyl moiety and (2) Co(Meacac) ${ }_{2} \mathrm{en}^{+}, \mathrm{Co}(\mathrm{acac})_{2} \mathrm{MeEn}^{+}$, and $\mathbf{C o}($ Meacac $){ }_{2} \mathbf{M e E n}^{+}$to confirm the shifts of the cathodic peak potential as a result of the different methylations $(\mathrm{MeEn}=$ $N$-methylethylenediamine; $\mathrm{PhEn}=\mathrm{N}$-phenylethylenediamine). The synthesis of the complexes followed a similar procedure as described above, and the only difference was the use of ammonium hexafluorophosphate for precipitation of the complexes (see details in the Experimental Section).

Indeed, cyclic voltammetric measurements performed for Co(acac $)_{2} \mathbf{P h E n}^{+}$showed a strong shift of the cathodic peak potential to $49 \mathrm{mV}$ in comparison to that of $\mathbf{C o}(\mathbf{a c a c}){ }_{2} \mathbf{e n}^{+}$at $-141 \mathrm{mV}$ (Figure 4). This can be explained by the electronwithdrawing effect of the phenyl ring, which distinctly increases the redox potential of the cobalt center. With regard to the methylations at the "en" versus the acac moiety, the model complexes confirmed (even more pronounced) the tendencies observed for the EGFR inhibitor-containing complexes [except $\mathrm{Co}$ (acac) ${ }_{2} \mathbf{M e E n}^{+}$with a slightly lower $E_{c}$ value]. The introduction of the methylated acac moiety led to a significantly

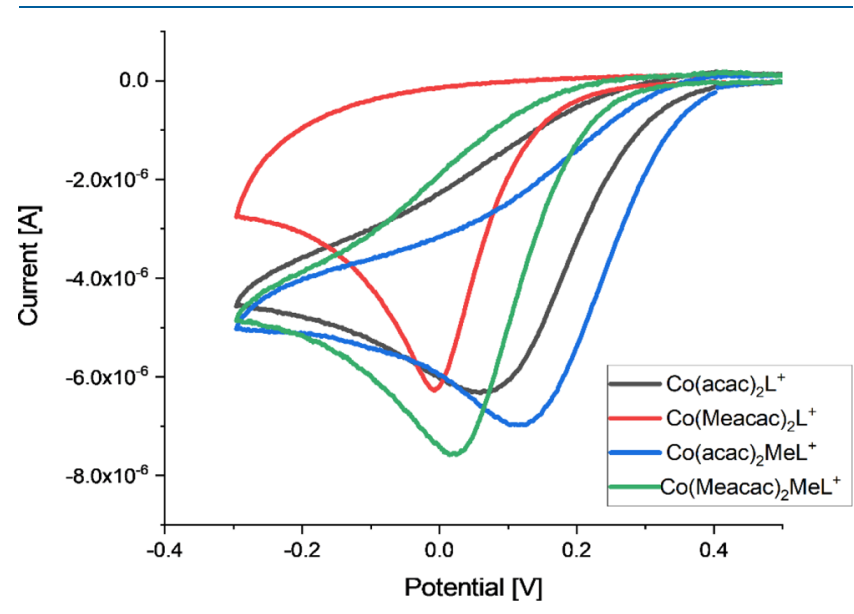

Figure 3. Cyclic voltammograms of $\mathrm{Co}(\mathrm{acac})_{2} \mathrm{~L}^{+}, \mathrm{Co}(\text { Meacac })_{2} \mathrm{~L}^{+}$, $\mathbf{C o}(\text { acac })_{2} \mathrm{MeL}^{+}$, and $\mathrm{Co}$ (Meacac) ${ }_{2} \mathrm{MeL}^{+}$in $10 \mathrm{mM}$ phosphate buffer $(\mathrm{pH} 7.40)(1.5 \mathrm{mM}$ complex, $I=0.10 \mathrm{M} \mathrm{KCl}$, scan rate of $30 \mathrm{mV} / \mathrm{s}, 25.0$ $\left.{ }^{\circ} \mathrm{C}\right)$. Potentials are referenced to the NHE. 

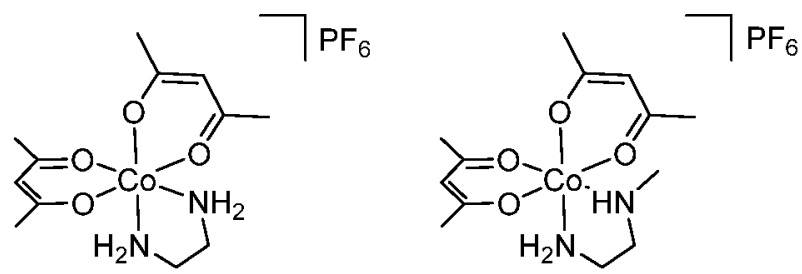

$$
\begin{aligned}
& \text { Co(acac })_{2} \mathrm{en}^{+} \\
& E_{c}=-141 \mathrm{mV}
\end{aligned}
$$

$$
\begin{aligned}
& \mathrm{Co}(\mathrm{acac})_{2} \mathrm{MeEn}^{+} \\
& \mathrm{E}_{\mathrm{c}}=-152 \mathrm{mV}
\end{aligned}
$$

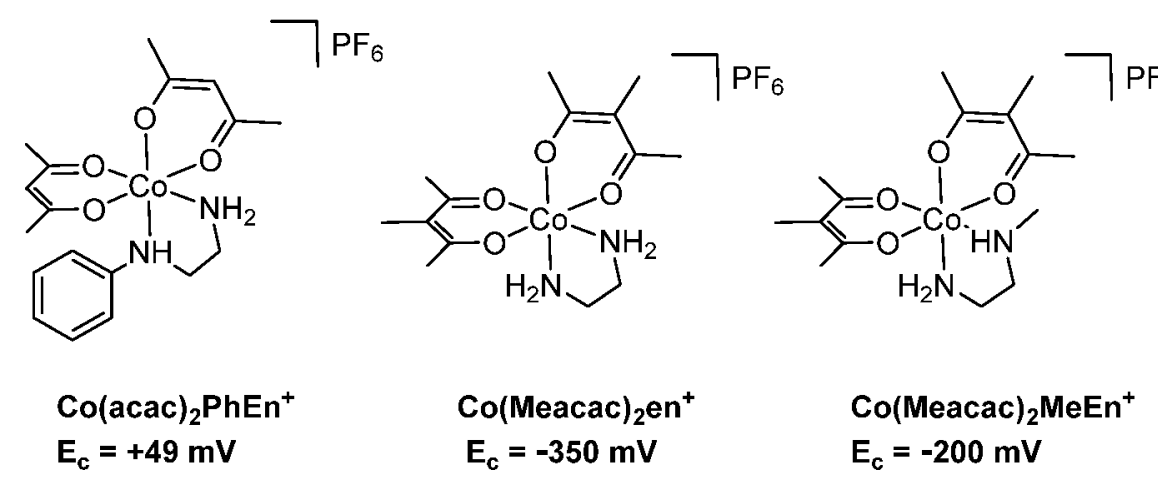

Figure 4. Cobalt(III) model complexes synthesized to investigate the effect of the methyl and phenyl substitution at the "en" and/or acac moiety. $E_{\mathrm{c}}$ is

\begin{tabular}{|c|c|c|c|c|}
\hline \multicolumn{3}{|c|}{$\operatorname{acac}(\mathrm{A})$} & $\operatorname{MeEn}(\mathrm{B})$ & PhEn (B) \\
\hline $\mathrm{p} K_{\mathrm{al}}$ & $8.80 \pm 0.01^{b}$ & $\mathrm{p} K_{\mathrm{al}}$ & $7.04 \pm 0.02$ & $1.85 \pm 0.01^{c}$ \\
\hline $\mathrm{p} K_{\mathrm{a} 2}$ & - & $\mathrm{p} K_{\mathrm{a} 2}$ & $9.98 \pm 0.01$ & $9.34 \pm 0.01^{c}$ \\
\hline \multicolumn{5}{|c|}{$\log \beta$ Values of the Binary Complexes ${ }^{\mathrm{c}}$} \\
\hline$[\mathrm{Co}(\mathrm{II}) \mathrm{L}]^{+}$ & $5.05 \pm 0.02^{b}$ & {$[\mathrm{Co}(\mathrm{II}) \mathrm{L}]^{2+}$} & $5.26 \pm 0.01$ & $3.63 \pm 0.05$ \\
\hline$\left[\mathrm{Co}(\mathrm{II}) \mathrm{L}_{2}\right]^{0}$ & $8.66 \pm 0.05^{b}$ & {$\left[\mathrm{Co}(\mathrm{II}) \mathrm{L}_{2}\right]^{2+}$} & $9.15 \pm 0.02$ & $6.75 \pm 0.09$ \\
\hline$\left[\mathrm{Co}(\mathrm{II}) \mathrm{L}_{3}\right]^{-}$ & - & {$\left[\mathrm{Co}(\mathrm{II}) \mathrm{L}_{3}\right]^{2+}$} & $12.94 \pm 0.04$ & - \\
\hline \multicolumn{5}{|c|}{$\log \beta$ Values of the Ternary Complexes } \\
\hline & & {$[\mathrm{Co}(\mathrm{II}) \mathrm{AB}]^{+}$} & $9.82 \pm 0.05$ & $8.03 \pm 0.15$ \\
\hline & & {$\left[\mathrm{Co}(\mathrm{II}) \mathrm{A}_{2} \mathrm{~B}\right]^{0}$} & $12.73 \pm 0.09$ & $12.08 \pm 0.09$ \\
\hline & & {$\left[\mathrm{Co}(\mathrm{II}) \mathrm{AB}_{2}\right]^{+}$} & $13.20 \pm 0.12$ & $11.29 \pm 0.13$ \\
\hline
\end{tabular}
the cathodic peak potential vs NHE of the cobalt complexes measured at a scan rate of $30 \mathrm{mV} / \mathrm{s}$ in $10 \mathrm{mM}$ phosphate buffer ( $\mathrm{pH} 7.4$ ).

Table 2. Proton Dissociation Constants $\left(K_{\mathrm{a}}\right)$ of Hacac as well as Fully Protonated MeEn and PhEn Together with the Overall Stability Constants $(\beta)$ for the Binary and Ternary Cobalt(II) Complexes Determined by pH-Potentiometric Measurements ${ }^{a}$

${ }^{a}$ In ternary (mixed-ligand) complexes, "A" denotes acac and "B" denotes MeEn or PhEn $\left[25.0{ }^{\circ} \mathrm{C} ; \mathrm{I}=0.1 \mathrm{M}(\mathrm{KCl})\right] .{ }^{b} \mathrm{Reported}$ data for the cobalt(II) acac system: $\mathrm{p} K_{\mathrm{a} 1}=8.83, \log \beta[\mathrm{CoL}]=5.10$, and $\log \beta\left[\mathrm{CoL}_{2}\right]=9.08\left(25^{\circ} \mathrm{C} ; I=0.1 \mathrm{M} \mathrm{NaClO}_{4}\right) .{ }^{40}{ }_{\mathrm{p}} K_{\mathrm{a}}$ values of $1.76 \pm 0.03$ and 9.42 \pm 0.03 , and $1.73 \pm 0.03$ and $9.37 \pm 0.03$, determined by ultraviolet-visible and spectrofluorometric titrations, respectively.

decreased reduction potential, whereas the methylation of the "en" ligand showed the opposite effect. Therefore, in the case of Co(Meacac) ${ }_{2} \mathbf{M e E n}^{+}$, the influence of the methylated acac moiety is widely annihilated by the methylation of "en".

Notably, all reduction processes were completely irreversible independent of the scan speed $(30-1000 \mathrm{mV} / \mathrm{s})$. In the literature, the proposed mechanism for cobalt(III) prodrugs usually comprises that in healthy tissues, which are provided with a sufficient supply of oxygen, and after the reduction to cobalt(II), an immediate re-oxidation step occurs, regenerating the inert cobalt(III) complex. ${ }^{23,30}$ However, at the same time for most of the cobalt(III) complexes in the literature, the redox process in an aqueous solution is completely irreversible. ${ }^{31-34}$ This is in line with pulse radiolysis studies also revealing that the re-oxidation rates under normoxic conditions are too slow. ${ }^{35}$ Instead, competition between oxygen and the cobalt(III) complexes for one-electron reductants was suggested. Interestingly, despite this irreversibility, e.g., cobalt(III) nitrogen mustard complexes showed promising hypoxia selective anticancer activity. ${ }^{32}$ In particular, Ware et al. tried to optimize the electrochemical properties of cobalt(III) prodrug systems, resulting in (partially) reversible complexes with highly hypoxia selective activity against cancer cells. ${ }^{36}$ Unfortunately, their lead compound did not show significant activity in a mouse model. However, as our compound class, which displays irreversible electrochemical properties, also possesses hypoxia-dependent anticancer activity in a mouse model, ${ }^{17}$ this indicates that the irreversibility of the reduction process does not interfere with the in vivo effectiveness. Therefore, it is currently unknown how the exact mechanism of the hypoxic selectivity of cobalt(III) complexes works and which electrochemical properties are ideal.

Aqueous Solution Stability of the Formed Cobalt(II) Complexes. After reductive activation of the cobalt(III) prodrugs, it is essential to investigate whether the formed cobalt(II) complexes indeed can release the coordinated targeting ligand. For this reason, we selected two ternary 
systems as models to study the potential liberation of the $(\mathrm{N}, \mathrm{N})$ ligand from the mixed-ligand cobalt complex upon reduction. Thus, the aqueous stability of several cobalt(II) complexes was investigated under strictly anaerobic conditions. Due to the limited water solubility of cobalt(II) chloride complexes with L, model ligands with better solubility, namely, MeEn and PhEn, were used. First, deprotonation processes of the acetlyacetone (Hacac) and the fully protonated MeEn and $\mathrm{PhEn}$ ligands were followed at $\mathrm{pH}$ 2.0-11.5 (Table 2). The calculated $\mathrm{p} K_{\mathrm{a}}$ for Hacac of 8.80 is in good agreement with literature data $\left(\mathrm{p} K_{\mathrm{a}}=\right.$ 8.82) reported at $I=0.1 \mathrm{M} \mathrm{NaClO}_{4} \cdot{ }^{37}$ The two $\mathrm{p} K_{\mathrm{a}}$ values of $\operatorname{MeEn}\left[\mathrm{p} K_{\mathrm{a} 1}=7.04\left(\mathrm{MeNH}_{2}^{+}\right) ; \mathrm{p} K_{\mathrm{a} 2}=9.98\left(\mathrm{NH}_{3}^{+}\right)\right]$ correspond well to the deprotonation constants of the fully protonated form of "en", 38,39 but the $\mathrm{p} K_{\mathrm{a} 1}$ dramatically differs from that of $\mathrm{PhEnH}_{2}{ }^{2+}\left(\mathrm{pK}_{\mathrm{a} 1}=1.85 ; \mathrm{p} K_{\mathrm{a} 2}=9.34\right)$. The latter model ligand is quite comparable to EGFR inhibitor $\mathbf{L}\left(\mathrm{p} K_{\mathrm{a} 1}<\right.$ 1.0; $\mathrm{pK}_{\mathrm{a} 2}=9.21$ ) investigated in our previous work. ${ }^{29}$

Following the determination of the stability constants for the binary complexes (Table 2), overall stability constants for the mixed-ligand complexes formed in the cobalt(II)-acac-MeEn and cobalt(II)-acac-PhEn ternary systems were calculated on the basis of $\mathrm{pH}$-potentiometric titrations. Three types of complexes were formed, $[\mathrm{CoAB}]^{+},\left[\mathrm{CoA}_{2} \mathrm{~B}\right]$, and $\left[\mathrm{CoAB}_{2}\right]^{+}$, where " $A$ " denotes acac and " $B$ " refers to MeEn or PhEn. Concentration distribution curves in Figure 5 were computed using the stability constants of the 1:2:1 cobalt(II)-acac-PhEn composition that corresponds to the reduced form of $\mathbf{C o}(\mathrm{II})$ (acac) ${ }_{2} \mathbf{L}^{0}$. On the basis of these data, negligible amounts $(<1 \%)$ of $\mathrm{PhEn}$ are coordinated to cobalt(II) at $\mathrm{pH}$ 7.4. For the 1:2:1 cobalt(II)-acac-MeEn system, $\sim 11 \%$ are still coordinated to cobalt(II) at pH 7.4 (Figure S6). However, it has to be mentioned that these calculations were performed for $1 \mathrm{mM}$ cobalt(II) (where the titrations were performed), and the amount of the intact ternary complex further decreases with lower concentrations [e.g., in the latter system at $\mathrm{pH} 7.4$ and 0.1 $\mathrm{mM}$ cobalt(II), the coordinated MeEn fraction is only $\sim 2 \%]$.

As a conclusion, these measurements strongly support the assumption that after reduction of the cobalt(III) complexes, the respective EGFR-targeting ligand completely dissociates, which enables subsequent inhibition of the EGFR-downstream signaling.

Interaction with Natural Low-Molecular Weight Reducing Agents. Next, we investigated if common bio-

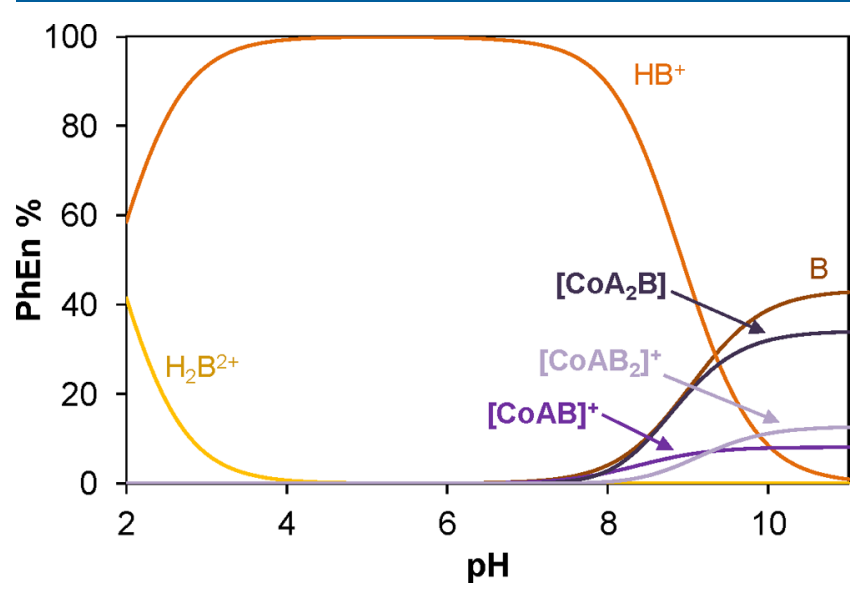

Figure 5. Concentration distribution diagram for the 1:2:1 cobalt(II)acac - PhEn system. A = acac; B = PhEn [1 mM cobalt(II); $I=0.10 \mathrm{M}$ $\left.(\mathrm{KCl}) ; 25.0{ }^{\circ} \mathrm{C}\right]$. logically relevant low-molecular weight reducing agents can reduce $\mathbf{C o}(\text { acac })_{2} \mathrm{~L}^{+}$or $\mathbf{C o}(\text { Meacac })_{2} \mathrm{~L}^{+}$. Glutathione $(\mathrm{GSH})$ and reduced nicotinamide adenine dinucleotide (phosphate) $(\mathrm{NADH} / \mathrm{NADPH})$ are responsible for the redox equilibrium in the cytosol, while ascorbic acid (AA) is found in both extra- and intracellular space. Among them, $\mathrm{NADH}$ is the strongest reducing agent (formal potential at $\mathrm{pH} 7.0$ of $-0.32 \mathrm{~V}$ for $\left.\mathrm{NAD}^{+} / \mathrm{NADH}^{41}\right)$, followed by GSH $(-0.24 \mathrm{~V}$ for GSSG/GSH at $\mathrm{pH} 7.0^{41}$ ). For AA, usually $0.06 \mathrm{~V}$ for dehydro-L-ascorbate/ $\mathrm{AA}$ at $\mathrm{pH} 7.0$ is reported. ${ }^{42}$ However, recent literature also suggests even higher values in the range of $0.35-0.50 \mathrm{~V} .^{43,44}$ $\mathrm{GSH}$ is produced in cells at concentrations $(1-10 \mathrm{mM})$ at least one order of magnitude higher than those of NADH (30-100 $\mu \mathrm{M}){ }^{45,46}$

The interaction of $\mathrm{AA}, \mathrm{GSH}$, and $\mathrm{NADH}$ at $\mathrm{pH} 7.40$ (phosphate buffer) was investigated exemplarily for Co(acac) ${ }_{2} \mathrm{~L}^{+}$and $\mathbf{C o}(\text { Meacac })_{2} \mathrm{~L}^{+}$. The reaction was followed by ultraviolet-visible (UV-vis) and fluorometric detection at 25 ${ }^{\circ} \mathrm{C}$ with a 10 -fold excess of reducing agent. Spectrofluorometry was proven to be an effective technique for monitoring this redox reaction, because the free EGFR inhibitor ligand $\mathbf{L}$ is highly fluorescent, while its cobalt(III) complex has negligible emission (vide supra). ${ }^{17}$ Accordingly, an increase in the emission intensity is expected upon reduction and concomitant release of the free ligand. Figure 6 indicates practically no reduction process of $\mathbf{C o}$ (Meacac) ${ }_{2} \mathrm{~L}^{+}$in the presence of 10 equiv of GSH, and no significant amount of free $\mathbf{L}$ appeared in samples even after $24 \mathrm{~h}$. The same tendency was observed by UV-vis detection (data not shown). For $\mathrm{Co}(\operatorname{acac})_{2} \mathbf{L}^{+}$, again no liberation of the active ligand could be detected within $24 \mathrm{~h}$. $\mathrm{AA}$ and NADH were also not able to reduce the two complexes even after $24 \mathrm{~h}$. These data show that the complexes are highly stable in aqueous solution and biologically relevant lowmolecular weight non-enzymatic reducing agents are not responsible for the reduction of the cobalt(III) complexes. For other hypoxia-activatable drugs like tirapazamine and its secondgeneration analogue SN30000, P450 oxidoreductases (POR) have been proposed as proteins responsible for reduction. ${ }^{47}$ However, Ware and co-workers ${ }^{36}$ and Wilson and co-workers ${ }^{48}$ showed for different types of cobalt(III) complexes that the cytotoxicity did not change in cells overexpressing POR

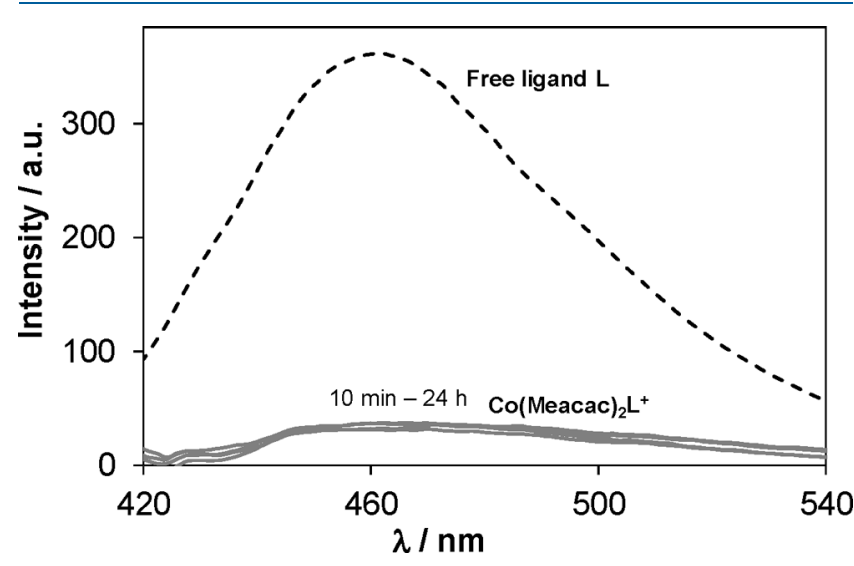

Figure 6. Fluorescence emission spectra of $\mathrm{Co}(\text { Meacac })_{2} \mathbf{L}^{+}$in the presence of 10 equiv of GSH followed for $24 \mathrm{~h}$. The dashed spectrum corresponds to the emission spectrum of free EGFR inhibitor $\mathbf{L}\left[c_{\text {complex }}\right.$ $=15 \mu \mathrm{M} ; c_{\text {free ligand }}=15 \mu \mathrm{M} ; \lambda_{\mathrm{EX}}=350 \mathrm{~nm} ; \mathrm{pH} 7.40(10 \mathrm{mM}$ phosphate buffer and $\left.0.1 \mathrm{M} \mathrm{KCl}) ; 25.0{ }^{\circ} \mathrm{C}\right]$. 

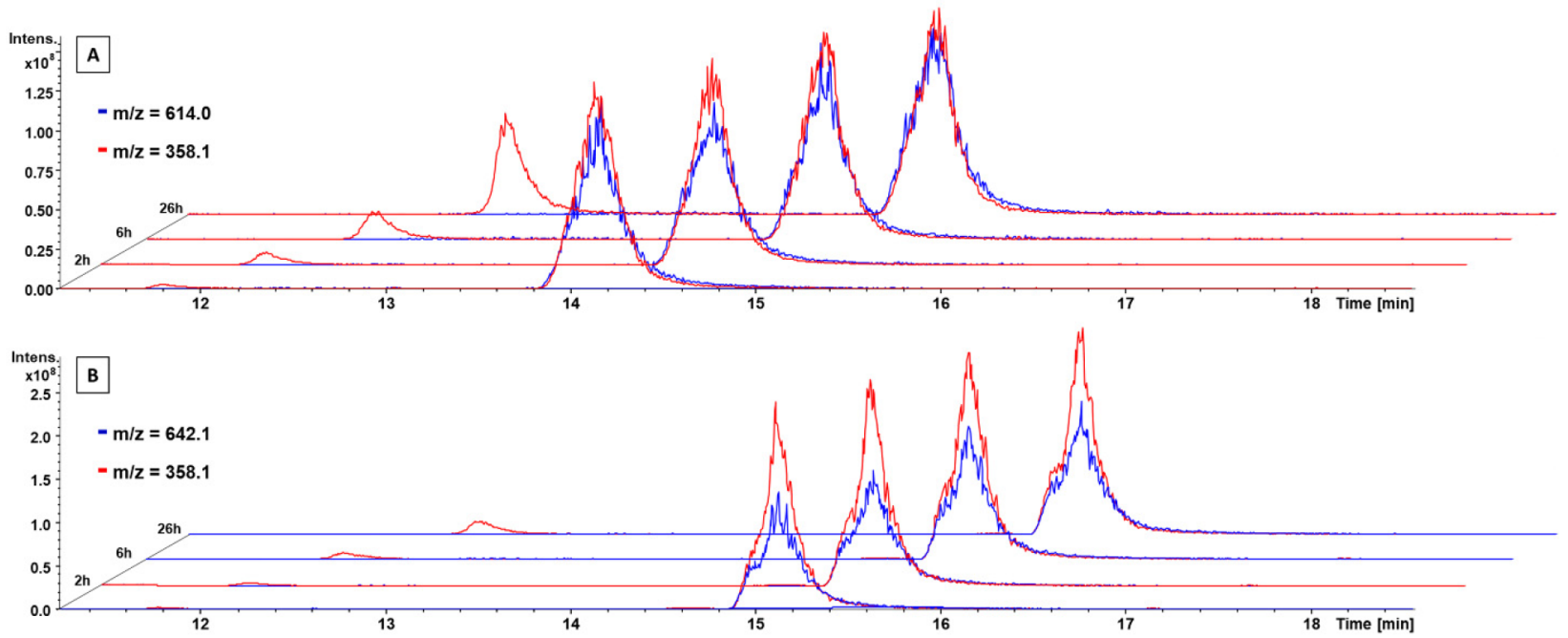

Figure 7. Time-dependent stability of (A) Co(acac) ${ }_{2} \mathrm{~L}^{+}$and (B) Co(Meacac) $)_{2} \mathrm{~L}^{+}$incubated in $\mathrm{FCS}$ at $37^{\circ} \mathrm{C}(\mathrm{pH} 7.4,150$ mM phosphate buffer) and analyzed by HPLC-mass spectrometry (depicted are the extracted ion mass chromatograms). Due to the different ionization properties, the intensities of the free ligand $(\mathrm{m} / z$ 358.1) and cobalt(III) complexes $(\mathrm{m} / z 614.0$ or 642.1$)$ cannot be directly compared.

compared to the parental cell line. Therefore, the actual reducing molecules or reductase(s) are still unknown.

Serum Stability. The data presented in the previous sections indicate that even in the presence of low-molecular weight reducing agents the cobalt(III) complexes are completely stable. Therefore, we wanted to investigate if this is still true in a more elaborate biological environment like blood serum. To this end, the four EGFR inhibitor complexes were dissolved in 50 $\mathrm{mM}$ phosphate puffer and mixed in a 1:10 ratio with fetal calf serum (FCS; buffered with $150 \mathrm{mM}$ phosphate buffer to keep a stable $\mathrm{pH}$ of 7.4) to a final concentration of $50 \mu \mathrm{M}$. The samples were incubated at $37^{\circ} \mathrm{C}$ and after $0,2,6,24$, and $26 \mathrm{~h}$ extracted with acetonitrile and measured by HPLC-MS. The extracted ion mass chromatogram of $\mathbf{C o}(\mathbf{a c a c})_{2} \mathrm{~L}^{+}$clearly showed the timedependent release of the free EGFR inhibitor (Figure 7A; red peak at $11.8 \mathrm{~min}, \mathrm{~m} / z$ 358.1). The intact complex could be observed at $14.2 \mathrm{~min}$ (blue peak, $m / z 614.0$ ). The red signal at the same retention time (Figure 7A; $14.2 \mathrm{~min}, \mathrm{~m} / z$ 358.1) is a mass spectrometry artifact and belongs to the free ligand generated during ionization of the complex. In contrast, the mass spectra of $\mathbf{C o}$ (Meacac) ${ }_{2} \mathrm{~L}^{+}$incubated in serum revealed much smaller amounts of the released ligand (Figure 7B).

The same trend was observed for $\mathbf{C o}(\mathbf{a c a c})_{2} \mathbf{M e L}^{+}$and Co(Meacac) ${ }_{2} \mathrm{MeL}^{+}$(Figure S7). Therefore, in this experiment, a distinct increase in the stability in the presence of the Meacac ligand could be observed in both complexes with $\sim 85 \%$ intact compound after serum incubation for $26 \mathrm{~h}$ at $37{ }^{\circ} \mathrm{C}$. The stability of these complexes was much higher than that of Co(acac) ${ }_{2} \mathrm{~L}^{+}$and $\mathbf{C o}($ acac $){ }_{2} \mathrm{MeL}^{+}$, having only $43 \%$ and $50 \%$ intact compound after $26 \mathrm{~h}$, respectively (Figure 8). In general, these results are in accordance with the cyclic voltammetry measurements, where $\mathbf{C o}($ Meacac $){ }_{2} \mathrm{~L}^{+}$and $\mathbf{C o}($ Meacac $){ }_{2} \mathrm{MeL}^{+}$ showed the lowest redox potential of the four complexes. Together, this indicates a strong influence of the methylation of acac for the stability of cobalt(III) prodrugs; however, no beneficial effect was seen in the case of methylation of the "en" moiety.

Biological Investigations. Evaluation of the Complex Stability in the Presence of Cells under Normoxic Conditions. As a next step, we addressed the question of whether the new derivatives are also more stable than $\mathrm{Co}(\mathrm{acac}){ }_{2} \mathrm{~L}^{+}$in the

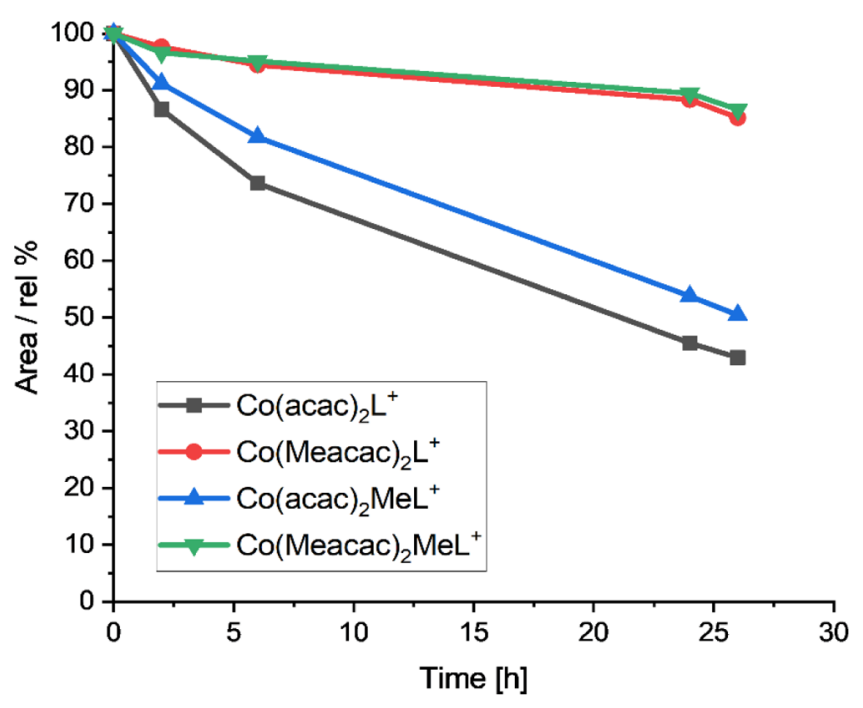

Figure 8. Stability measurements of $\mathrm{Co}(\mathrm{acac})_{2} \mathrm{~L}^{+}, \mathrm{Co}(\mathrm{Meacac})_{2} \mathrm{~L}^{+}$, $\mathrm{Co}(\mathrm{acac})_{2} \mathrm{MeL}^{+}$, and $\mathrm{Co}(\mathrm{Meacac}){ }_{2} \mathrm{MeL}^{+}$incubated in $\mathrm{FCS}$ at $37^{\circ} \mathrm{C}$ ( $\mathrm{pH} 7.4,150 \mathrm{mM}$ phosphate buffer) and analyzed by mass spectrometry over a period of $26 \mathrm{~h}$. The $y$-axis shows the relative ratio of the integrated peak areas of the intact complex over time (in percent) compared to the area at the starting point $(0 \mathrm{~h})$.

presence of cells under normoxic cell culture conditions (medium containing $10 \%$ serum at $37{ }^{\circ} \mathrm{C}, 21 \% \mathrm{O}_{2}$, and $5 \%$ $\mathrm{CO}_{2}$ ). Therefore, the stability of the cobalt(III) complexes was monitored indirectly by microscopy as well as flow cytometry in A431 cells by exploiting the fluorescence of released ligands $\mathbf{L}$ and MeL. As shown in Figure 9, the stability of the compounds bearing a Meacac ligand was distinctly increased compared to those of the acac derivatives. Consequently, while in case of the acac drugs most of the ligand was already released after $24 \mathrm{~h}$ (clearly visible by the blue fluorescence of the cells), the micrographs of the Meacac compounds remained widely unchanged.

This also could be confirmed by subsequently performed flow cytometry investigations (Figure 10). In detail, the evaluation of the fluorescence intensities showed that the cobalt complexation led to a 1.9-2.6-fold reduced mean fluorescence and a 4-90- 
A auto fluorescence
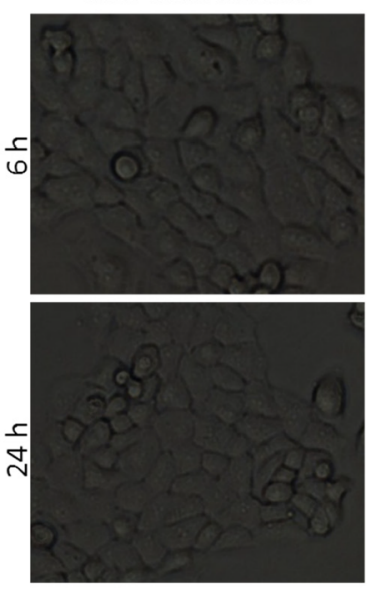

B
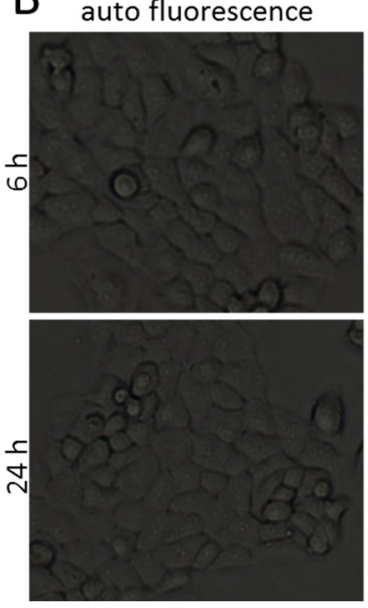

L
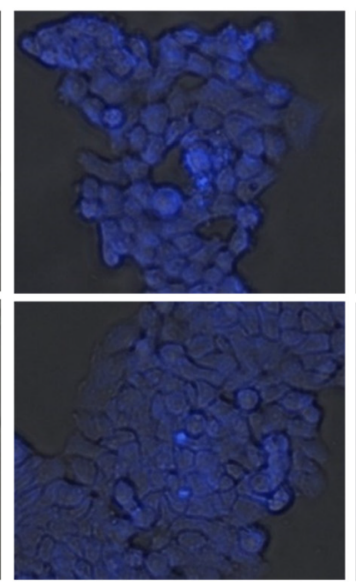

MeL
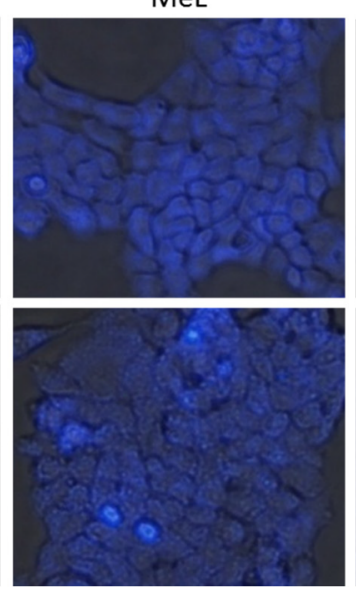

$\mathrm{Co}(\text { acac })_{2} \mathrm{~L}^{+}$
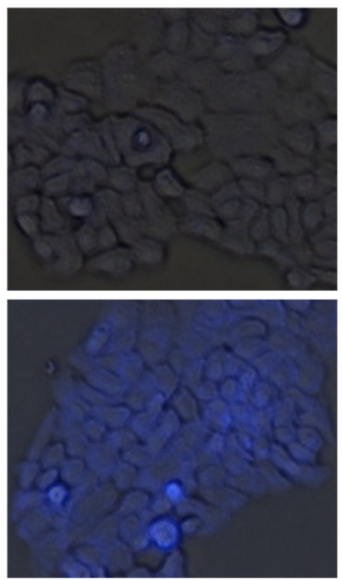

$\mathrm{Co}(\mathrm{acac})_{2} \mathrm{MeL}^{+}$
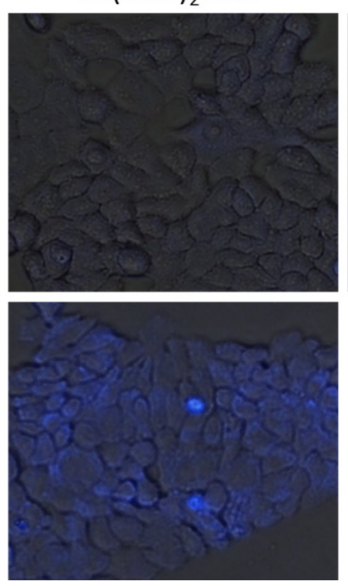

$\mathrm{Co}(\text { Meacac })_{2} \mathrm{~L}^{+}$


$\mathrm{Co}(\text { Meacac })_{2} \mathrm{MeL}^{+}$
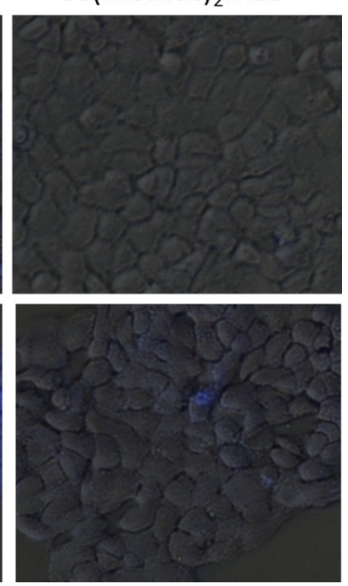

Figure 9. Fluorescence microscopic measurements indicating the release of the ligand from the different cobalt(III) complexes. Release of (A) $\mathbf{L}$ and (B) $\mathrm{MeL}$ from the different cobalt(III) complexes under normoxic cell culture conditions $\left(37^{\circ} \mathrm{C}, 21 \% \mathrm{O}_{2}\right.$, and $\left.5 \% \mathrm{CO}_{2}\right)$ using $\mathrm{UV}$ fluorescence microscopy. A431 cells were incubated with $10 \mu \mathrm{M}$ drugs for 6 or $24 \mathrm{~h}$. Images are overlays of representative fluorescence and differential interference contrast microscopies (10× objective) of the different treatments processed by ImageJ software.

fold reduced number of ligand-positive cells at the $6 \mathrm{~h}$ time point. This is in good agreement with the already published data on $\mathrm{Co}($ acac $){ }_{2} \mathrm{~L}^{+} .{ }^{17}$ However, after incubation for $24 \mathrm{~h} 100 \%$ of cells treated with the two acac complexes became ligandpositive, resulting in a mean fluorescence similar to that of the samples treated with the free ligand. In contrast, in the samples of the Meacac-containing group, the mean fluorescence was much less affected, as the percentage of ligand-positive cells increased only from $2.2 \%$ to $18.4 \%$ and from $1 \%$ to $7.5 \%$, in the cases of $\mathrm{Co}($ Meacac $){ }_{2} \mathrm{~L}^{+}$and $\mathrm{Co}($ Meacac $){ }_{2} \mathrm{MeL}^{+}$, respectively. This indicates that in contrast to the acac-auxiliary ligand, the cobalt(III) complexes bearing a Meacac moiety are highly stable under normoxic cell culture conditions for more than 1 day.

To evaluate if cobalt complexation also prevents EGFR inhibition under normoxic conditions, Western blot analyses of the EGFR phosphorylation at position Y1068 (activating phosphorylation) as well as the activation of the EGFR downstream protein ERK 1/2 were performed. To ensure an EGFR-dependent signaling, A431 cells were serum-starved for $24 \mathrm{~h}$, incubated with the indicated cobalt(III) drugs at three different concentrations for $2 \mathrm{~h}$, and stimulated by EGF for $10 \mathrm{~min}$ prior to protein isolation (Figure 11). In agreement with our stability data, the Meacac ligand set efficiently prevented the release of both $\mathrm{L}$ and $\mathrm{MeL}$, indicated by the distinctly weakened
EGFR-inhibitory potential of $\mathbf{C o}$ (Meacac $)_{2} \mathrm{~L}^{+}$and Co(Meacac) ${ }_{2} \mathrm{MeL}^{+}$in comparison to $\mathrm{Co}(\mathrm{acac}){ }_{2} \mathrm{~L}^{+}$and $\mathbf{C o}$ (acac) ${ }_{2} \mathrm{MeL}^{+}$. The potent EGFR inhibition by free $\mathbf{M e L}$ and $\mathbf{L}$ under these conditions is shown in Figure S8 and ref 17, respectively.

Hypoxia-Dependent Cytotoxicity of the Cobalt Complexes. Finally, we wanted to evaluate whether the Meacac coordination sphere also affects the hypoxic activation of the complexes. To characterize the activity of the free EGFR inhibitor ligands, prior to the assessment of their anticancer activity in cell culture, the EGFR-inhibitory potential was investigated in a cell-free kinase inhibition assays in the presence of a 10-fold excess of ATP. The results showed that the methylation at the terminal amino group slightly reduced the EGFR inhibition potential from an $\mathrm{IC}_{50}$ value of $0.29 \mathrm{nM}$ for $\mathbf{L}$ to a value of $0.41 \mathrm{nM}$ for MeL (Figure S9).

Subsequently, MTT-based cytotoxicity assays of the complexes in comparison to the respective metal-free ligands were performed under different $\mathrm{O}_{2}$ levels $(21 \%, 5 \%, 1 \%$, or $0.1 \%)$ (Table 3 and Figure 12). As expected, the two EGFR inhibitor ligands $\mathbf{L}$ and $\mathbf{M e L}$ did not show distinct differences in their anticancer activity in normoxic versus the different hypoxic conditions. However, MeL was approximately twice as effective as $\mathbf{L}$. This is interesting, as the kinase assay mentioned above did 
A
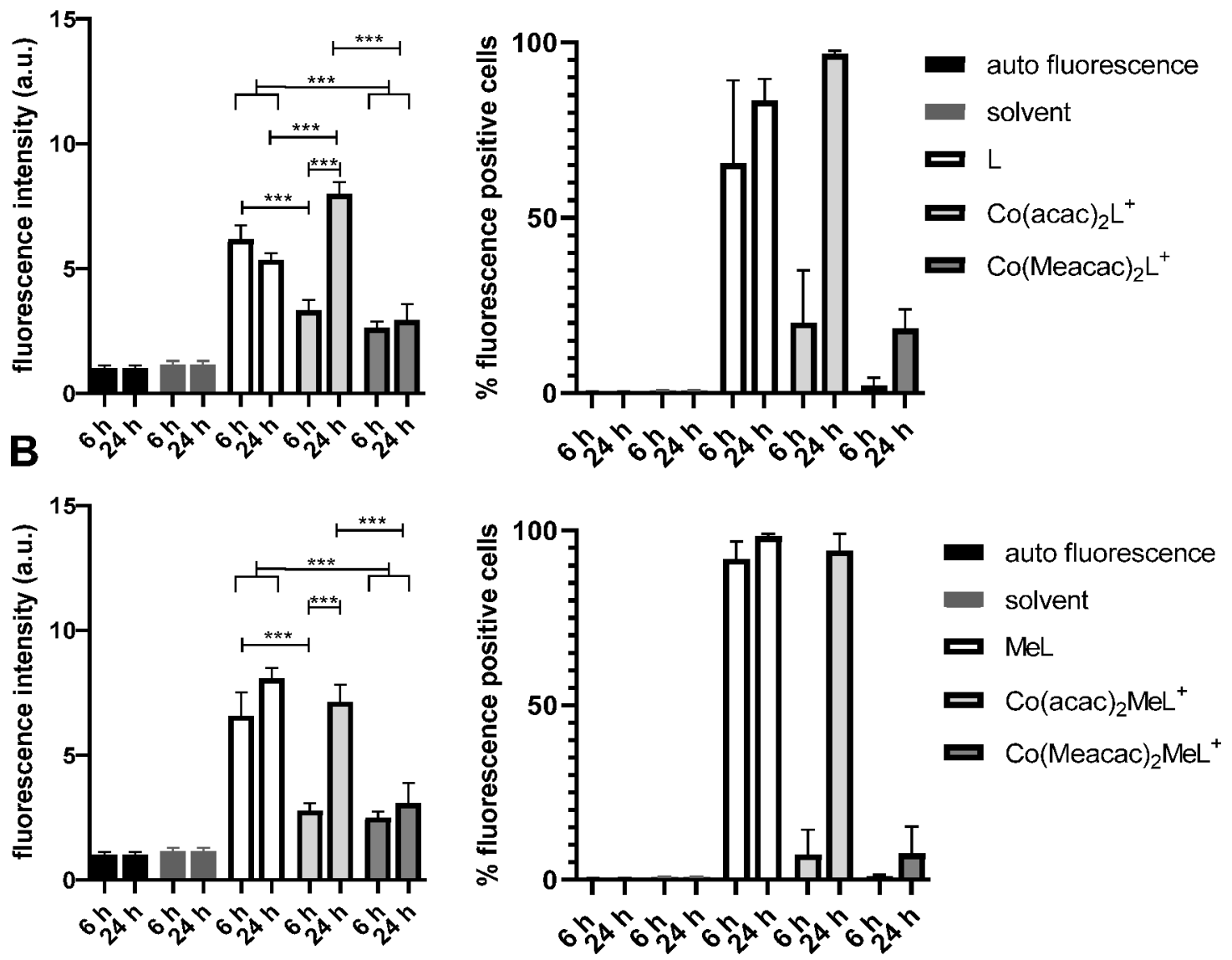

Figure 10. Release of (A) L or (B) MeL from the indicated cobalt(III) complexes under normoxic cell culture conditions $\left(37^{\circ} \mathrm{C}, 21 \% \mathrm{O}_{2}\right.$, and $5 \%$ $\mathrm{CO}_{2}$ ) by flow cytometry. A431 cells were incubated with $10 \mu \mathrm{M}$ drugs for 6 or $24 \mathrm{~h}$, and the fold change in fluorescence intensity (left, after normalization with fluorescence intensity of the cells) and the percent of fluorescence-positive cells (right) were evaluated using Diva Software and GraphPad Prism. Statistical significance was calculated via two-way analysis of variance with a multiple-comparison test and Bonferroni correction with $p<0.001(* * *)$.
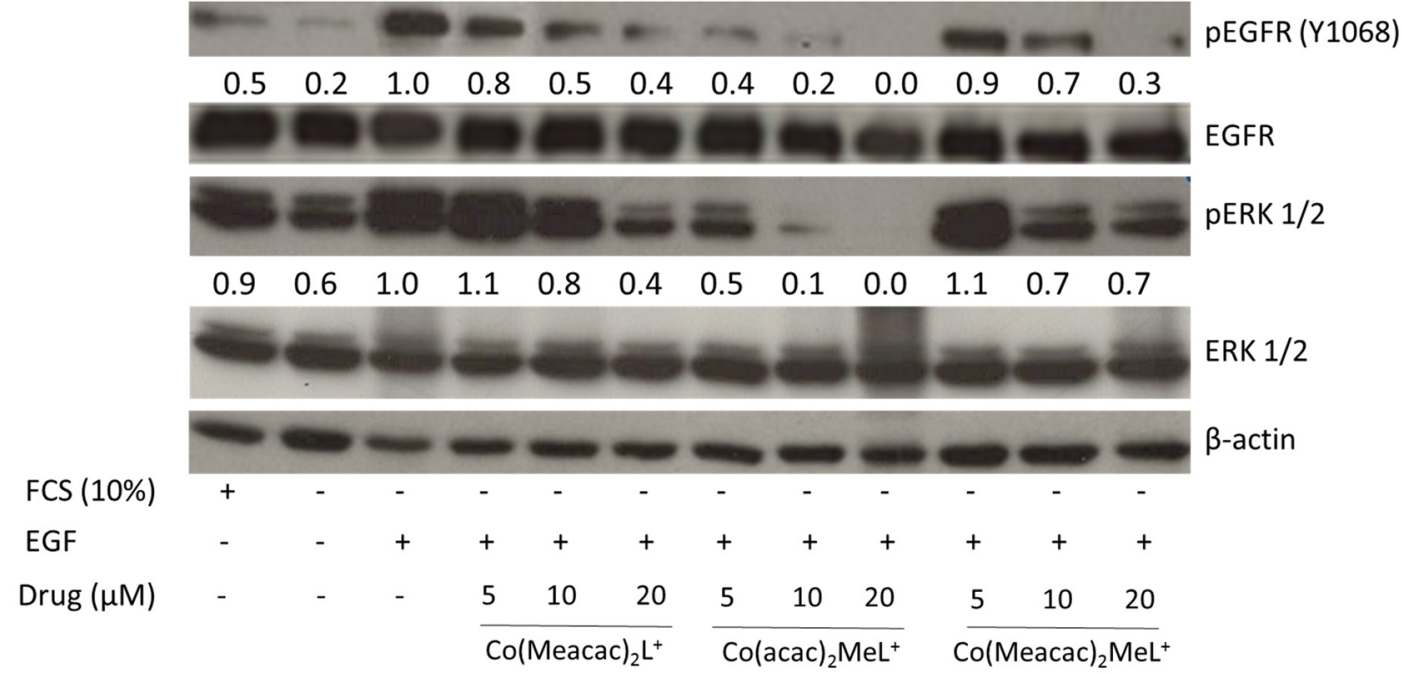

Figure 11. Impact of new cobalt(III) complexes on the EGFR signaling cascade (pEGFR, pERK 1/2) under normoxic conditions. A431 cells were grown in medium with or without FCS and treated with the indicated drug for $2 \mathrm{~h}$. After EGFR stimulation with $50 \mathrm{ng} / \mathrm{mL}$ EGF for $10 \mathrm{~min}$, cells were harvested, lysated, and further analyzed by Western blotting. The ratios of pEGFR or pERK $1 / 2$ levels of the treated samples (after normalization to the loading control $\beta$-actin) to the levels of the control (-FCS and $+\mathrm{EGF})$ are given below the respective bands. 
Table 3. $\mathrm{IC}_{50}$ Values of $\mathrm{L}$ and $\mathrm{MeL}$ in Comparison to the Respective Cobalt(III) Prodrugs against A431 Cancer Cells after Treatment for $72 \mathrm{~h}$ under Different $\mathrm{O}_{2}$ Levels $(21 \% \text { to } 0.1 \%)^{a}$

\begin{tabular}{lcccc} 
& \multicolumn{3}{c}{$\mathrm{IC}_{50}(\mu \mathrm{M} \pm \mathrm{SD})$} \\
\cline { 2 - 5 } \multicolumn{1}{c}{ drug } & normoxia & hypoxia with $5 \% \mathrm{O}_{2}$ & hypoxia with $1 \% \mathrm{O}_{2}$ & hypoxia with $0.1 \% \mathrm{O}_{2}$ \\
$\mathbf{M e L}$ & $12.0 \pm 1.3$ & $12.8 \pm 0.9$ & $12.7 \pm 2.0$ & $13.7 \pm 2.9$ \\
$\mathbf{C o}(\mathrm{acac})_{2} \mathbf{L}^{+}$ & $6.9 \pm 1.8$ & $8.7 \pm 1.2$ & $5.5 \pm 0.4$ & $5.4 \pm 0.8$ \\
$\mathbf{C o}(\mathrm{Meacac})_{2} \mathbf{L}^{+}$ & $22.9 \pm 5.7^{b}$ & $18.7 \pm 4.0^{b}$ & $13.4 \pm 0.3$ & $7.2 \pm 1.4$ \\
$\mathbf{C o}(\mathbf{a c a c})_{2} \mathbf{M e L}^{+}$ & $51.9 \pm 9.4^{c, e}$ & $45.5 \pm 2.7^{c}$ & $25.3 \pm 3.9$ & $23.5 \pm 5.1$ \\
$\mathbf{C o}(\mathbf{M e a c a c})_{2} \mathbf{M e L}^{+}$ & $15.1 \pm 1.6$ & $13.5 \pm 3.2$ & $12.5 \pm 3.1$ & $11.9 \pm 3.5$ \\
erlotinib & $58.6 \pm 4.4^{c, e}$ & $55.2 \pm 1.4^{c}$ & $32.0 \pm 2.9^{d}$ & $19.9 \pm 1.0$ \\
\end{tabular}

${ }^{a}$ Values are given as means \pm SD of at least three independent experiments performed in triplicate. Statistical significance, between the drugs under normoxic and different hypoxic conditions, was calculated via one-way analysis of variance with a multiple-comparison test and Bonferroni correction. ${ }^{b} p<0.01$ compared to hypoxia with $0.1 \% \mathrm{O}_{2} \cdot{ }^{c} p<0.001$ compared to hypoxia with $1 \%$ and $0.1 \% \mathrm{O}_{2} .{ }^{d} p<0.05$ compared to hypoxia with $0.1 \% \mathrm{O}_{2} \cdot{ }^{e} p<0.001$ compared to the corresponding ligand and $\mathrm{Co}(\mathrm{acac})_{2} \mathrm{X}^{+}$derivative under normoxia.
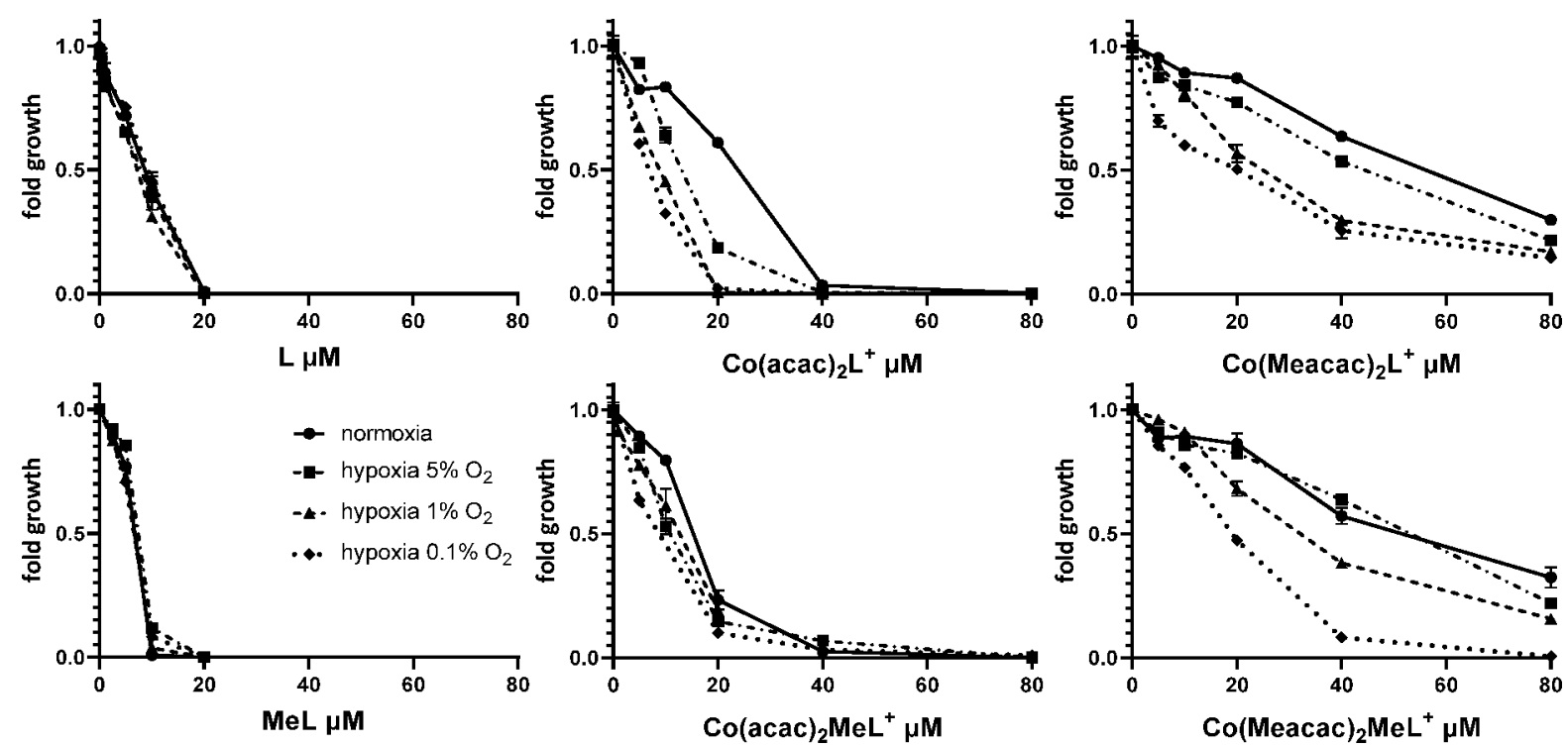

Figure 12. Cytotoxic activity of the indicated compounds against A431 cancer cells. The incubation time of the compounds on the cells was $72 \mathrm{~h}$ under normoxic and three different hypoxic conditions $\left(5 \%, 1 \%\right.$, or $\left.0.1 \% \mathrm{O}_{2}\right)$. Values are given as means \pm the standard deviation of one representative experiment performed in triplicate.

not show a higher EGFR inhibitor potency for this new inhibitor, probably indicating a shift in the target kinase spectrum.

In good agreement with our previous study, ${ }^{17}$ the formerly investigated $\mathrm{Co}(\mathrm{acac}){ }_{2} \mathrm{~L}^{+}$exhibited an $\sim 2$-fold weaker anticancer activity under normoxia (Table 3 ) than under reduced oxygen conditions $(\leq 1 \%)$. Also in the case of $\mathbf{C o}(\mathbf{a c a c}){ }_{2} \mathbf{M e L}^{+}$, the cobalt complex was $\sim 2$-fold less active than the respective free ligand. However, under hypoxic conditions, Co(acac) ${ }_{2} \mathrm{MeL}^{+}$did not show full MeL activity even under the lowest oxygen levels of $0.1 \%$. In contrast, the two Meacaccontaining cobalt(III) complexes both showed $\mathrm{IC}_{50}$ values of $>50 \mu \mathrm{M}$ under normoxic conditions and also weak hypoxia with $5 \% \mathrm{O}_{2}$ did not enhance the activity to a relevant extent. However, the reduction of oxygen levels to $1 \%$ significantly $(p<$ 0.001 ) increased the cytotoxic activity of the two prodrugs, resulting in $\mathrm{IC}_{50}$ values of $\sim 25$ and $\sim 32 \mu \mathrm{M}$ for Co(Meacac) ${ }_{2} \mathrm{~L}^{+}$ and $\mathbf{C o}(\text { Meacac })_{2} \mathbf{M e L}^{+}$, respectively. In the case of Co(Meacac) ${ }_{2} \mathrm{~L}^{+}$, a further decrease in the $\mathrm{O}_{2}$ levels from $1 \%$ to $0.1 \%$ generated similar results. In contrast, for Co(Meacac) ${ }_{2} \mathrm{MeL}^{+}$, the presence of $0.1 \% \mathrm{O}_{2}$ induced an additional significant $(p<0.05)$ improvement in drug efficacy $\left(\mathrm{IC}_{50}\right.$ value of $\sim 20 \mu \mathrm{M})$ compared to that for $1 \% \mathrm{O}_{2}$ hypoxia, resulting in a 2.9-fold increase in cytotoxicity compared to that under normoxic conditions.

It is well-known that cobalt(II) ions have some biological effects like an upregulation of the expression of the hypoxia inducible factor (HIF). ${ }^{49}$ Furthermore, a possible effect could also arise from iron(III) binding of released Meacac. ${ }^{50}$ However, we already investigated in our previous work ${ }^{17} \mathrm{CoCl}_{2}$ as well as the complexes $\left[\mathrm{Co}(\mathrm{II})(\mathrm{acac})_{2} \mathrm{en}\right]$ and $\left[\mathrm{Co}(\mathrm{III})(\mathrm{acac})_{2} \mathrm{en}\right] \mathrm{PF}_{6}$ with a simple ethylenediamine ligand without an EGFR-binding moiety. No significant cytotoxic activity could be observed against A431 cells under both normoxia and hypoxia. Therefore, we can widely exclude a contribution of $\mathrm{Co}$ (II) ions or released acac (and subsequent iron chelation) on the anticancer activity of EGFR inhibitor-bearing cobalt(III) prodrugs.

\section{CONCLUSIONS}

Despite the revolutionizing effect they have had on cancer therapy, TKIs are limited in their clinical application due to severe side effects and rapid development of drug resistance. Hence, the design of tumor-specifically activated prodrugs is an important strategy for reducing these adverse effects. We 
recently established a hypoxia-activatable cobalt(III) prodrug bearing an EGFR inhibitor ligand $\left[\mathrm{Co}(\operatorname{acac})_{2} \mathrm{~L}^{+}\right]$, which showed promising results in vitro as well as in vivo. ${ }^{17}$ The aim of this study was to further improve the stability of this type of prodrug by introducing electron-donating methyl groups to lower the reduction potential. Methylation was performed at the chelating moiety of the EGFR inhibitor and/or the acac ancillary ligand. Interestingly, methylation of the EGFR inhibitor ligand $\left[\mathrm{Co}(\mathrm{acac}){ }_{2} \mathrm{MeL}^{+}\right]$alone did not result in the expected lower cobalt(III) reduction potential. However, this aim was reached using Meacac as the ancillary ligand, and complexes Co(Meacac) ${ }_{2} \mathrm{~L}^{+}$and $\mathrm{Co}($ Meacac $){ }_{2} \mathrm{MeL}^{+}$showed highly increased stability in blood plasma. This stability trend could also be confirmed in cell culture using fluorescence microscopy and flow cytometry, exploiting the quenched fluorescence of the EGFR inhibitor ligand when coordinated to cobalt(III). Evaluation of the cytotoxic activity of all compounds under normoxia versus hypoxia revealed that the complexes with distinctly higher stability still possess promising hypoxia-activatable properties. However, the $\mathrm{IC}_{50}$ values at $0.1 \% \mathrm{O}_{2}$ after $72 \mathrm{~h}$ were significantly higher compared to those of the free EGFR inhibitor ligands. More in-depth studies are now needed to evaluate the underlying reasons for this effect. Finally, a balance between sufficient stability of the complex and tumor-specific release of the EGFR inhibitor ligand is needed. However, only evaluation in future in vivo experiments will reveal whether Co(Meacac) ${ }_{2} \mathrm{MeL}^{+}$is a promising candidate with both high stability and activity.

\section{EXPERIMENTAL SECTION}

Materials and Methods. All solvents and reagents were obtained from commercial suppliers. They were, unless stated otherwise, used without further purification. Anhydrous $\mathrm{MeOH}$ and tetrahydrofuran over molecular sieves were bought from Fisher Chemicals. The precursors $\mathrm{Na}\left[\mathrm{Co}(\mathrm{acac})_{2}\left(\mathrm{NO}_{2}\right)_{2}\right]$ and $\mathrm{Na}\left[\mathrm{Co}(\text { Meacac })_{2}\left(\mathrm{NO}_{2}\right)_{2}\right]$ were obtained following the protocol of Denny et al. ${ }^{21} \mathbf{C o}(\mathbf{a c a c})_{2} \mathbf{e n}^{+}$, $\operatorname{Co}(\operatorname{acac})_{2} \mathrm{~L}^{+}$, and $\mathbf{L}$ were synthesized according to our previous publication. ${ }^{17}$

For all HPLC measurements, Milli-Q water $(18.2 \mathrm{M} \Omega \mathrm{cm}$, Merck Milli-Q Advantage, Merck, Darmstadt, Germany) was used. Preparative RP-HPLC was performed on an Agilent 1200 Series system controlled by Chemstation software. As the stationary phase, either a XBridge BEH C18 OBD Prep Column (130 ̊, $5 \mu \mathrm{m}, 19 \mathrm{~mm} \times 250 \mathrm{~mm})$ or an Atlantis T3 OBD Prep Column (100 ̊, $10 \mu \mathrm{m}, 19 \mathrm{~mm} \times 250 \mathrm{~mm})$, each from Waters Corp., was used. The general procedure included a flow rate of $17.06 \mathrm{~mL} / \mathrm{min}$, an injection volume of $\leq 10 \mathrm{~mL}$, and a column temperature of $25{ }^{\circ} \mathrm{C}$. Milli-Q water and acetonitrile (ACN) without addition of acids were used as eluents unless stated otherwise. Stability and kinetic experiments were analyzed on an Agilent 1260 Infinity system using a Waters Atlantis T3 column $(150 \mathrm{~mm} \times 4.6 \mathrm{~mm})$ coupled to a Bruker amaZon SL ESI mass spectrometer. If not stated otherwise, water (containing $0.1 \%$ formic acid) and ACN (containing $0.1 \%$ formic acid) were used as eluents with a gradient of $1 \%$ to $99 \%$ ACN within $29 \mathrm{~min}$. Elemental analyses were performed by the Microanalytical Laboratory of the University of Vienna on a Perkin Elmer $2400 \mathrm{CHN}$ Elemental Analyzer. Electrospray ionization (ESI) mass spectra were recorded on a Bruker amaZon SL ion trap mass spectrometer in positive and/or negative mode by direct infusion. High-resolution mass spectra were recorded on a Bruker maXis UHR ESI time-of-flight mass spectrometer. Expected and experimental isotope distributions were compared. ${ }^{1} \mathrm{H}$ and ${ }^{13} \mathrm{C}$ NMR one- and twodimensional spectra were recorded in DMSO- $d_{6}$ with a Bruker FTNMR AV NEO $500 \mathrm{MHz}$ spectrometer at $500.10\left({ }^{1} \mathrm{H}\right)$ and 125.75 $\left({ }^{13} \mathrm{C}\right) \mathrm{MHz}$ at $298 \mathrm{~K}$ or a Bruker FT-NMR AVIII $600 \mathrm{MHz}$ spectrometer at $600.25 \mathrm{MHz}\left({ }^{1} \mathrm{H}\right)$ and $150.93 \mathrm{MHz}\left({ }^{13} \mathrm{C}\right)$. Chemical shifts (parts per million) were referenced internally to the solvent residual peaks. For the description of the spin multiplicities the following abbreviations were used: $s$, singlet; $d$, doublet; $t$, triplet; $q$, quartet; $\mathrm{m}$, multiplet. For the NMR description of the synthesized compounds, the following abbreviations were used: acac, acetylacetone; Meacac, methylacetylacetone; en, ethylenediamine; MeEn, $N$-methylethylenediamine; phEn, $\mathrm{N}$-phenylethylenediamine; ph, phenyl; quin, quinazoline.

Synthesis. tert-Butyl [2-(\{4-[(3-Bromophenyl)amino]quinazolin6-yl\}amino)ethyl](methyl)carbamate. N-(3-Bromophenyl)quinazoline-4,6-diamine $(1.5 \mathrm{~g}, 4.81 \mathrm{mmol})$ was dissolved in absolute $\mathrm{MeOH}(47 \mathrm{~mL})$ under an argon atmosphere. Freshly distilled acetic acid $(276 \mu \mathrm{L}, 4.81 \mathrm{mmol})$ and molecular sieves $(823 \mathrm{mg}, 3-4 \AA$, dried overnight at $150{ }^{\circ} \mathrm{C}$ ) were added. $\mathrm{N}$-Boc-(methylamino)-acetaldehyde $(1 \mathrm{~g}, 5.77 \mathrm{mmol})$ was dissolved in absolute $\mathrm{MeOH}(5 \mathrm{~mL})$, and the mixture was added dropwise to the yellow reaction solution. After the mixture had been stirred for $1 \mathrm{~h}$, sodium cyanoborohydride $(363 \mathrm{mg}$, 5.77 equiv) was added in small portions and the reaction mixture was allowed to stir overnight under an argon atmosphere. The next day the solvent was removed, and the yellow residue was extracted in $600 \mathrm{~mL}$ of EtOAc and washed with $400 \mathrm{~mL}$ of $1 \mathrm{M} \mathrm{HCl}$, saturated $\mathrm{NaHCO}_{3}$, and brine. The organic phase was separated, dried over $\mathrm{Na}_{2} \mathrm{SO}_{4}$, and concentrated in vacuo. The crude product was purified via flash chromatography (15:1 dichloromethane/MeOH). Yield: $1.48 \mathrm{~g}(65 \%)$. ${ }^{1} \mathrm{H}$ NMR $\left(500.1 \mathrm{MHz}\right.$, DMSO- $\left.d_{6}\right): \delta 1.19(\mathrm{~s}, 6 \mathrm{H}), 1.39(\mathrm{~s}, 3 \mathrm{H}), 1.41(\mathrm{~s}$, $3 \mathrm{H}), 2.77-2.93(\mathrm{~m}, 2 \mathrm{H}), 3.42-3.50(\mathrm{~m}, 2 \mathrm{H}), 6.31(\mathrm{~d}, J=8.0 \mathrm{~Hz}, 1 \mathrm{H})$, $7.91-7.31(\mathrm{~m}, 3 \mathrm{H}), 7.35(\mathrm{t}, 1 \mathrm{H}), 7.56(\mathrm{~d}, J=2.0 \mathrm{~Hz}, 1 \mathrm{H}), 7.91(\mathrm{~d}, J=$ $2.0 \mathrm{~Hz}, 1 \mathrm{H}), 8.17(\mathrm{~s}, 1 \mathrm{H}), 8.39(\mathrm{~s}, 1 \mathrm{H}), 9.34(\mathrm{~d}, J=6.0 \mathrm{~Hz}, 1 \mathrm{H})$.

$N^{4}$-(3-Bromophenyl)- $N^{6}$-[2-(methylamino)ethyl]quinazoline-4,6diamine Dihydrochloride (MeL). To a solution of tert-butyl [2-(\{4[(3-bromophenyl)amino] quinazolin-6-yl\}amino)ethyl] (methyl)carbamate $(1.48 \mathrm{~g}, 3.12 \mathrm{mmol})$ in EtOH $(30 \mathrm{~mL})$ was added concentrated $\mathrm{HCl}(1.25 \mathrm{~mL}, 40.0 \mathrm{mmol})$, and the reaction mixture was refluxed for $3 \mathrm{~h}$. The solution was cooled to room temperature and stored overnight at $4{ }^{\circ} \mathrm{C}$. The yellow precipitate was filtered off, washed with $\mathrm{EtOH}$, and dried in vacuo. Yield: $1.11 \mathrm{~g} \mathrm{(80 \% ).}{ }^{1} \mathrm{H}$ NMR $(600.25$ MHz, DMSO- $\left.d_{6}\right): \delta 2.61(\mathrm{t}, 3 \mathrm{H}, \mathrm{H} 23), 3.15(\mathrm{~m}, 2 \mathrm{H}, \mathrm{H} 21), 3.67(\mathrm{~m}$, $2 \mathrm{H}, \mathrm{H} 20), 7.19$ (s, 1H, H18), 7.45 (t, 3H, H16), 7.48-7.54 (m, 2H, H2, $\mathrm{H} 15), 7.77(\mathrm{~d}, 1 \mathrm{H}, J=2.0 \mathrm{~Hz}, \mathrm{H} 3), 7.88(\mathrm{~d}, 1 \mathrm{H}, J=2.0 \mathrm{~Hz}, \mathrm{H} 11), 8.00$ (s, 1H, H6), 8.13 (s, 1H, H13), 8.78 (s, 1H, H8), 9.09 (s, 2H, H22), 11.50 (s, $1 \mathrm{H}, \mathrm{H} 17) .{ }^{13} \mathrm{C}$ NMR $\left(150.93 \mathrm{MHz}, \mathrm{DMSO}-d_{6}\right): \delta 32.45$ (C23), 38.93 (C21), 46.20 (C20), 98.57 (C6), 115.42 (C5), 120.73 (C3), 121.00 (C14), 123.71 (C11), 126.53 (C2), 127.23 (C13), 128.72 (C15), 130.41 (C16), 130.88 (C4), 138.67 (C12), 146.30 (C8), 148.57 (C1), 158.23 (C10). MS: calcd for $\left[\mathrm{C}_{17} \mathrm{H}_{18} \mathrm{BrN}_{5}\right]^{+}, 372.08$; found, 372.08. Anal. Calcd for $\mathrm{C}_{17} \mathrm{H}_{18} \mathrm{BrN}_{5} \cdot 2 \mathrm{HCl}\left(M_{\mathrm{r}}=445.18 \mathrm{~g} / \mathrm{mol}\right)$ : C, 45.86; H, 4.53; N, 15.73. Found: C, 45.75; H, 4.22; N, 15.47 .

Bis(3-methyl-2,4-pentanedionato) $N^{6}$-(2-Aminoethyl)- $N^{4}-(3-$ bromophenyl)quinazoline-4,6-diamine Cobalt(III) Chloride [Co(Meacac) $\left.{ }_{2} \mathrm{~L}^{+}\right]$. Na[Co(Meacac $\left.)_{2}\left(\mathrm{NO}_{2}\right)_{2}\right](84.4 \mathrm{mg}, 0.22 \mathrm{mmol})$ was dissolved in $\mathrm{H}_{2} \mathrm{O}(1.6 \mathrm{~mL})$ and $\mathrm{MeOH}(4.5 \mathrm{~mL})$. L (100 mg, 0.23 mmol) was dissolved in $\mathrm{H}_{2} \mathrm{O}(1 \mathrm{~mL})$, neutralized with $\mathrm{NaOH}(1.65$ $\mathrm{mL}, 0.28 \mathrm{M}$ in $\mathrm{MeOH}$ ), and subsequently added to the cobalt precursor solution together with activated charcoal $(64 \mathrm{mg})$. The resulting mixture was stirred for $1 \mathrm{~h}$ at room temperature, filtered through Celite, and washed with small amounts of a $\mathrm{MeOH} / \mathrm{H}_{2} \mathrm{O}$ mixture (1:1). Brine<smiles>CNCCNc1ccc2ncnc(Nc3cccc(Br)c3)c2c1</smiles>

MeL 
$(30 \mathrm{~mL})$ was added to the filtrate, and the resulting solution was left at 4 ${ }^{\circ} \mathrm{C}$ overnight. The formed green precipitate was filtered off the next day. The crude product ( $250 \mathrm{mg}$ of a dark green solid) was purified by RPHPLC (Xbridge, $\mathrm{H}_{2} \mathrm{O} / \mathrm{MeOH}$, isocratic 57:43, without formic acid or TFA to avoid counter ion exchange). Yield: $67 \mathrm{mg}$ (44\%). The ratio of the two isomers was 1:0.36.

Shifts of the main isomer. ${ }^{1} \mathrm{H}$ NMR $\left(500.1 \mathrm{MHz}\right.$, DMSO- $\left.d_{6}\right): \delta 1.00$ (s, $3 \mathrm{H}, \mathrm{CH}_{3}$, Meacac), 1.65 (s, 3H, $\mathrm{CH}_{3}$, Meacac), 1.88 (s, $3 \mathrm{H}, \mathrm{CH}_{3}$, Meacac), 2.05-2.06 (m, 6H, $\mathrm{CH}_{3}$, Meacac), $2.35\left(\mathrm{~s}, 3 \mathrm{H}, \mathrm{CH}_{3}\right.$, Meacac), 2.67-2.97 (m, 3H, $\mathrm{CH}_{2}$, en), 3.60-3.69 (m, $1 \mathrm{H}, \mathrm{CH}_{2}$, en), 5.28-5.37 [m, 1H, CH, $\left.\mathrm{NH}_{2}(\mathrm{en})\right], 5.73-5.80\left[\mathrm{~m}, 1 \mathrm{H}, \mathrm{CH}, \mathrm{NH}_{2}(\mathrm{en})\right]$, $7.36-7.43(\mathrm{~m}, 2 \mathrm{H}, \mathrm{ph}), 7.52(\mathrm{dd}, 1 \mathrm{H}, J=9 \mathrm{~Hz}, J=2 \mathrm{~Hz}$, quin), 7.67 (d, $1 \mathrm{H}, J=9 \mathrm{~Hz}$, quin), $7.82-7.89(\mathrm{~m}, 1 \mathrm{H}, \mathrm{ph}), 7.93$ [d, $1 \mathrm{H}, \mathrm{NH}(\mathrm{en})], 8.10$ (s, $1 \mathrm{H}, \mathrm{ph}), 8.14-8.17(\mathrm{~m}, 1 \mathrm{H}$, quin), $8.65-8.70(\mathrm{~m}, 1 \mathrm{H}$, quin), 10.12 $(\mathrm{s}, 1 \mathrm{H}, \mathrm{NH}) .{ }^{13} \mathrm{C}$ NMR $\left(125.75 \mathrm{MHz}, \mathrm{DMSO}-d_{6}\right): \delta 13.8\left(\mathrm{CH}_{3}\right.$, Meacac), $14.9\left(\mathrm{CH}_{3}\right.$, Meacac), $26.1\left(2 \mathrm{C}, \mathrm{CH}_{3}\right.$, Meacac), 26.5 (2C, $\mathrm{CH}_{3}$, Meacac), $41.8\left(\mathrm{CH}_{2}\right.$, en $), 50.9\left(\mathrm{CH}_{2}\right.$, en $), 98.3\left(\mathrm{C}_{\mathrm{q}}\right.$, Meacac $)$, $100.5\left(\mathrm{C}_{\mathrm{q}}\right.$, Meacac $), 113.4(\mathrm{CH}$, quin $) *, 121.2\left(\mathrm{C}_{\mathrm{q}}, \mathrm{ph}\right), 121.3(\mathrm{CH}$, $\mathrm{ph}), 124.7(\mathrm{CH}, \mathrm{ph}), 126.5(2 \mathrm{C}, \mathrm{CH}$, quin $+\mathrm{ph}), 130.0(\mathrm{CH}$, quin $) *$, $130.6(\mathrm{CH}, \mathrm{ph}), 140.6\left(\mathrm{C}_{\mathrm{q}}, \mathrm{ph}\right), 142.8(\mathrm{Cq}$, quin $), 153.7(\mathrm{CH}$, quin $) *$, $157.0\left(\mathrm{C}_{\mathrm{q}}\right.$, quin $), 186.2\left(\mathrm{C}_{\mathrm{q}}\right.$, acac $), 186.9\left(\mathrm{C}_{\mathrm{q}}, \mathrm{acac}\right), 187.3\left(\mathrm{C}_{\mathrm{q}}\right.$, acac $)$, $187.9\left(\mathrm{C}_{\mathrm{q}}\right.$, acac $)$.

Shifts of the minor isomer. ${ }^{1} \mathrm{H}$ NMR $\left(500.1 \mathrm{MHz}\right.$, DMSO- $\left.d_{6}\right): \delta 1.77$ (s, 3H, $\mathrm{CH}_{3}$, Meacac), 1.78 (s, 3H, $\mathrm{CH}_{3}$, Meacac), 1.99 (s, $3 \mathrm{H}, \mathrm{CH}_{3}$, Meacac), 2.05-2.06 (m, 3H, $\mathrm{CH}_{3}$, Meacac), 2.20 (s, 3H, $\mathrm{CH}_{3}$, Meacac), 2.34 (s, 3H, $\mathrm{CH}_{3}$, Meacac), $2.67-2.97$ (m, 3H, en), 3.72$3.80\left(\mathrm{~m}, 1 \mathrm{H}\right.$, en), 5.28-5.37 [m, 1H, $\left.\mathrm{NH}_{2}(\mathrm{en})\right], 5.73-5.80[\mathrm{~m}, 1 \mathrm{H}$, $\mathrm{NH}_{2}$ (en)], 7.18 (dd, $1 \mathrm{H}, J=9 \mathrm{~Hz}, J=2 \mathrm{~Hz}$, quin), 7.36-7.43 (m, $2 \mathrm{H}$, ph), $7.46[\mathrm{~m}, 1 \mathrm{H}, \mathrm{NH}(\mathrm{en})], 7.71(\mathrm{~d}, 1 \mathrm{H}, J=9 \mathrm{~Hz}$, quin), $7.82-7.89(\mathrm{~m}$, $1 \mathrm{H}, \mathrm{ph}), 8.14-8.17(\mathrm{~m}, 1 \mathrm{H}, \mathrm{ph}), 8.65-8.70(\mathrm{~m}, 2 \mathrm{H}$, quin), 10.25 (s, $1 \mathrm{H}, \mathrm{NH}) .{ }^{13} \mathrm{C}$ NMR $\left(125.75 \mathrm{MHz}\right.$, DMSO- $\left.d_{6}\right): \delta 14.7\left(\mathrm{CH}_{3}\right.$, Meacac $)$, $14.9\left(\mathrm{CH}_{3}, \text { Meacac }\right)^{*}, 25.9\left(\mathrm{CH}_{3}\right.$, Meacac $), 26.6\left(\mathrm{CH}_{3}\right.$, Meacac $), 26.8$ $\left(\mathrm{CH}_{3}\right.$, Meacac $), 26.7\left(\mathrm{CH}_{3}\right.$, Meacac $), 51.2\left(\mathrm{CH}_{2} \text {, en }\right)^{*}, 52.2\left(\mathrm{CH}_{2}\right.$, en)*, $100.4\left(\mathrm{C}_{\mathrm{q}}\right.$, Meacac $), 100.6\left(\mathrm{C}_{\mathrm{q}}\right.$, Meacac $), 114$ (2C, $\mathrm{CH}$, quin $) *$, $121.3(\mathrm{CH}, \mathrm{ph}) *, 124.7(\mathrm{CH}, \mathrm{ph}) *, 126.5(2 \mathrm{C}, \mathrm{CH},-$ quin $+\mathrm{ph}) *$, $129.3(\mathrm{CH}, \text { quin })^{*}, 130.6(\mathrm{CH}, \mathrm{ph}) *, 153.7(\mathrm{CH}$, quin $) *, 187.7\left(\mathrm{C}_{\mathrm{q}}\right.$, Meacac), $188.2\left(\mathrm{C}_{\mathrm{g}}\right.$, Meacac).

MS: calcd for $\left[\mathrm{C}_{28} \mathrm{H}_{34} \mathrm{BrCoN}_{5} \mathrm{O}_{4}\right]^{+}, 642.11$; found, 642.28. Anal. Calcd for $\mathrm{C}_{28} \mathrm{H}_{34} \mathrm{BrClCoN}_{5} \mathrm{O}_{4} \cdot 2 \mathrm{H}_{2} \mathrm{O}\left(M_{\mathrm{r}}=714.92 \mathrm{~g} / \mathrm{mol}\right): \mathrm{C}$, 47.04; $\mathrm{H}, 5.36$; N, 9.80. Found: C, 46.85; H, 5.09; N, 9.68. *Detected only in two-dimensional (2D) NMR.

Bis(2,4-pentanedionato) $N^{4}-(3-B r o m o p h e n y l)-N^{6}-[2-$ (methylamino)ethyl]quinazoline-4,6-diamine Cobalt(III) Chloride $\left[\mathrm{Co}(\mathrm{acac})_{2} \mathrm{MeL}^{+}\right]$. Na[Co(acac $\left.)_{2}\left(\mathrm{NO}_{2}\right)_{2}\right](83.6 \mathrm{mg}, 0.23 \mathrm{mmol})$ was dissolved in $\mathrm{H}_{2} \mathrm{O}(1.6 \mathrm{~mL})$ and $\mathrm{MeOH}(1.6 \mathrm{~mL})$. MeL (105 mg, 0.24 mmol) was dissolved in $\mathrm{H}_{2} \mathrm{O}(1.1 \mathrm{~mL})$, neutralized with $\mathrm{NaOH}$ (1.9 $\mathrm{mL}, 0.25 \mathrm{M}$ in $\mathrm{MeOH}$ ), and subsequently added to the cobalt complex solution with activated charcoal $(55.2 \mathrm{mg})$. The resulting mixture was stirred for $1 \mathrm{~h}$ at room temperature, filtered through Celite, and washed with small amounts of $\mathrm{MeOH}$. Brine $(6.1 \mathrm{~mL})$ was added to the filtrate, and the resulting solution was extracted with dichloromethane $(3 \times 10$ $\mathrm{mL}$ ). The organic phase was separated, dried with $\mathrm{Na}_{2} \mathrm{SO}_{4}$, and evaporated. The crude product (115 $\mathrm{mg}$ of a dark green solid) was purified by RP-HPLC $\left(\mathrm{H}_{2} \mathrm{O} / \mathrm{ACN}, 30-42 \% \mathrm{ACN}, 26 \mathrm{~min}\right.$, without formic acid or TFA to avoid counter ion exchange). Yield: $63 \mathrm{mg}$ (40\%). The ratio of the four isomers (A:B:C:D) was 1:0.42:0.33:0.20.

Shifts of the main isomer A. ${ }^{1} \mathrm{H}$ NMR $\left(500.1 \mathrm{MHz}, \mathrm{DMSO}-d_{6}\right): \delta$ $1.56\left(\mathrm{~s}, 3 \mathrm{H}, \mathrm{CH}_{3}, \mathrm{acac}\right), 1.77$ (d, $\left.3 \mathrm{H}, J=6 \mathrm{~Hz}, \mathrm{CH}_{3}, \mathrm{MeEn}\right), 2.01(\mathrm{~s}, 3 \mathrm{H}$, $\left.\mathrm{CH}_{3}, \mathrm{acac}\right), 2.02\left(\mathrm{~s}, 3 \mathrm{H}, \mathrm{CH}_{3}, \mathrm{acac}\right), 2.30\left(\mathrm{~s}, 3 \mathrm{H}, \mathrm{CH}_{3}\right.$, acac), 2.58-3.04 (m, 3H, $\left.\mathrm{CH}_{2}, \mathrm{MeEn}\right), 3.68-3.92\left(\mathrm{~m}, 1 \mathrm{H}, \mathrm{CH}_{2}, \mathrm{MeEn}\right), 4.79(\mathrm{~s}, 1 \mathrm{H}$, $\mathrm{CH}$, acac), 5.67-5.75 (m, 1H, CH, acac), $6.74[\mathrm{~m}, 1 \mathrm{H}, \mathrm{NH}(\mathrm{en})]$, $7.33-7.43(\mathrm{~m}, 2 \mathrm{H}, \mathrm{CH}, \mathrm{ph}), 7.46(\mathrm{dd}, 1 \mathrm{H}, \mathrm{CH}, J=8 \mathrm{~Hz}, J=2 \mathrm{~Hz}$, quin), 7.61-7.73 (m, 1H, CH, quin), 7.83-7.94 (m, $1 \mathrm{H}, \mathrm{CH}, \mathrm{ph}), 8.13$ $(\mathrm{t}, 1 \mathrm{H}, \mathrm{CH}, \mathrm{ph}), 8.23-8.27(\mathrm{~m}, 1 \mathrm{H}, \mathrm{CH}$, quin), $8.29-8.38[\mathrm{~m}, 1 \mathrm{H}$, $\mathrm{NH}(\mathrm{en})], 8.62-8.70\left(\mathrm{~m}, 1 \mathrm{H}, \mathrm{CH}\right.$, quin), $10.13(\mathrm{~s}, 1 \mathrm{H}, \mathrm{NH}) .{ }^{13} \mathrm{C} \mathrm{NMR}$ (125.75 MHz, DMSO- $\left.d_{6}\right): \delta 26.2\left(\mathrm{CH}_{3}, \mathrm{acac}\right), 26.4\left(\mathrm{CH}_{3}, \mathrm{acac}\right), 26.5$ $\left(\mathrm{CH}_{3}, \mathrm{acac}\right), 26.6\left(\mathrm{CH}_{3}, \mathrm{acac}\right), 37.5\left(\mathrm{CH}_{3}, \mathrm{MeEn}\right), 50.8\left(\mathrm{CH}_{2}, \mathrm{MeEn}\right)$, $53.1\left(\mathrm{CH}_{2}, \mathrm{MeEn}\right), 96.4(\mathrm{CH}, \mathrm{acac}), 98.8(\mathrm{CH}, \mathrm{acac}), 115.7\left(\mathrm{C}_{\mathrm{q}}\right.$ quin $)^{*}, 121.6\left(\mathrm{C}_{\mathrm{q}}, \mathrm{ph}\right), 121.8(\mathrm{CH}, \mathrm{ph}), 125.3(\mathrm{CH}, \mathrm{ph}), 127.0(\mathrm{CH}$, ph), $127.5(\mathrm{CH}$, quin $), 130.9(\mathrm{CH}$, quin $), 131.0(\mathrm{CH}, \mathrm{ph}), 141.1\left(\mathrm{C}_{\mathrm{q}}\right.$ ph), 142.7 ( $\mathrm{C}_{\mathrm{q}}$ quin), 148.5 (Cq, quin)*, 157.5 (Cq, quin), $189.6\left(\mathrm{C}_{\mathrm{q}}\right.$, acac), 189.7 ( $\mathrm{C}_{\mathrm{q}}$, acac $), 190.0\left(\mathrm{C}_{\mathrm{q}}\right.$, acac $), 190.9\left(\mathrm{C}_{\mathrm{q}}\right.$, acac $)$.

Shifts of isomer B. ${ }^{1} \mathrm{H}$ NMR $\left(500.1 \mathrm{MHz}\right.$, DMSO- $\left.d_{6}\right): \delta 1.68(\mathrm{~s}, 3 \mathrm{H}$, $\mathrm{CH}_{3}$, acac), 2.06 (d, 3H, J $\left.=6 \mathrm{~Hz}, \mathrm{CH}_{3}, \mathrm{MeEn}\right), 2.03\left(\mathrm{~s}, 3 \mathrm{H}, \mathrm{CH}_{3}, \mathrm{acac}\right)$, $2.11\left(\mathrm{~s}, 3 \mathrm{H}, \mathrm{CH}_{3}, \mathrm{acac}\right), 2.26\left(\mathrm{~s}, 3 \mathrm{H}, \mathrm{CH}_{3}, \mathrm{acac}\right), 2.58-3.04(\mathrm{~m}, 3 \mathrm{H}$, $\left.\mathrm{CH}_{2}, \mathrm{MeEn}\right), 3.68-3.92\left(\mathrm{~m}, 1 \mathrm{H}, \mathrm{CH}_{2}, \mathrm{MeEn}\right), 5.55$ (s, $\left.1 \mathrm{H}, \mathrm{CH}, \mathrm{acac}\right)$, 5.67-5.75 (m, 1H, CH, acac), $6.18[\mathrm{~m}, 1 \mathrm{H}, \mathrm{NH}(\mathrm{en})], 7.29(\mathrm{dd}, 1 \mathrm{H}$, $\mathrm{CH}, J=8 \mathrm{~Hz}, J=2 \mathrm{~Hz}$, quin), 7.33-7.43 (m, 2H, CH, ph), 7.61-7.73 (m, 1H, CH, quin), 7.83-7.94 [m, 2H, CH, ph $+\mathrm{NH}(\mathrm{en})], 8.16(\mathrm{~m}$, $1 \mathrm{H}, \mathrm{CH}, \mathrm{ph}), 8.62-8.70(\mathrm{~m}, 1 \mathrm{H}, \mathrm{CH}$, quin), 8.70-8.74 (m, $1 \mathrm{H}, \mathrm{CH}$, quin), $10.23(\mathrm{~s}, 1 \mathrm{H}, \mathrm{NH}) .{ }^{13} \mathrm{C} \mathrm{NMR}\left(125.75 \mathrm{MHz}, \mathrm{DMSO}-d_{6}\right): \delta 26.5$ $\left(\mathrm{CH}_{3}, \mathrm{acac}\right), 26.8\left(\mathrm{CH}_{3}, \mathrm{acac}\right), 26.9\left(\mathrm{CH}_{3}, \mathrm{acac}\right), 27.0\left(\mathrm{CH}_{3}, \mathrm{acac}\right)$, $35.8\left(\mathrm{CH}_{3}, \mathrm{MeEn}\right), 49.8\left(\mathrm{CH}_{2}, \mathrm{MeEn}\right), 53.5\left(\mathrm{CH}_{2}, \mathrm{MeEn}\right), 98.3(2 \mathrm{C}$, $\mathrm{CH}, \mathrm{acac}), 115.7\left(\mathrm{C}_{\mathrm{Q}}, \text { quin }\right)^{*}, 116.1(\mathrm{CH}$, quin $) *, 121.6\left(\mathrm{C}_{\mathrm{q}}, \mathrm{ph}\right)$, $121.7(\mathrm{CH}, \mathrm{ph}), 125.2(\mathrm{CH}, \mathrm{ph}), 126.9(\mathrm{CH}, \mathrm{ph}), 127.5(\mathrm{CH}$, quin $)$, $129.6\left(\mathrm{CH}\right.$, quin), $131.0(\mathrm{CH}, \mathrm{ph}), 141.3\left(\mathrm{C}_{\mathrm{q}}, \mathrm{ph}\right), 142.5\left(\mathrm{C}_{\mathrm{q}}\right.$ quin $)$, $148.5\left(\mathrm{C}_{\mathrm{q}} \text {, quin }\right)^{*}, 157.8\left(\mathrm{C}_{\mathrm{q}}\right.$, quin $), 189.0\left(\mathrm{C}_{\mathrm{q}}\right.$, acac $), 189.7\left(\mathrm{C}_{\mathrm{q}}, \mathrm{acac}\right)$, $189.8\left(\mathrm{C}_{\mathrm{q}}, \mathrm{acac}\right), 190.1\left(\mathrm{C}_{\mathrm{q}}, \mathrm{acac}\right)$.

Shifts of isomer C. ${ }^{1} \mathrm{H}$ NMR $\left(500.1 \mathrm{MHz}\right.$, DMSO- $\left.d_{6}\right): \delta 1.76(\mathrm{~s}, 3 \mathrm{H}$, $\mathrm{CH}_{3}$, acac), 1.90 (d, $\left.3 \mathrm{H}, J=6 \mathrm{~Hz}, \mathrm{CH}_{3}, \mathrm{MeEn}\right), 1.99\left(\mathrm{~s}, 3 \mathrm{H}, \mathrm{CH}_{3}, \mathrm{acac}\right)$, $2.07\left(\mathrm{~s}, 3 \mathrm{H}, \mathrm{CH}_{3}, \mathrm{acac}\right), 2.26\left(\mathrm{~s}, 3 \mathrm{H}, \mathrm{CH}_{3}, \mathrm{acac}\right), 2.58-3.04(\mathrm{~m}, 3 \mathrm{H}$, $\left.\mathrm{CH}_{2}, \mathrm{MeEn}\right), 4.16-4.27$ (m, 1H, $\left.\mathrm{CH}_{2}, \mathrm{MeEn}\right), 5.51$ (s, $\left.1 \mathrm{H}, \mathrm{CH}, \mathrm{acac}\right)$, 5.67-5.75 (m, 1H, CH, acac), $6.87[\mathrm{~m}, 1 \mathrm{H}, \mathrm{NH}(\mathrm{en})], 7.25(\mathrm{dd}, 1 \mathrm{H}$, $\mathrm{CH}, J=8 \mathrm{~Hz}, J=2 \mathrm{~Hz}$, quin), 7.33-7.43 (m, 2H, CH, ph), 7.61-7.73 (m, 1H, CH, quin), 7.83-7.94 [m, 1H, NH(en)], 7.98 (d, 1H, J = 9.0 $\mathrm{Hz}, \mathrm{CH}, \mathrm{ph}), 8.16$ (m, 1H, CH, ph), $8.62-8.70(\mathrm{~m}, 1 \mathrm{H}, \mathrm{CH}$, quin), $8.98\left(\mathrm{~s}, 1 \mathrm{H}, \mathrm{CH}\right.$, quin), 10.33 (s, 1H, NH). ${ }^{13} \mathrm{C} \mathrm{NMR}(125.75 \mathrm{MHz}$, DMSO-d $\left.d_{6}\right): \delta 26.5\left(\mathrm{CH}_{3}, \mathrm{acac}\right)^{*}, 26.7\left(\mathrm{CH}_{3}, \mathrm{acac}\right)^{*}, 27.0\left(\mathrm{CH}_{3}\right.$, acac $)^{*}, 27.1\left(\mathrm{CH}_{3}, \mathrm{acac}\right)^{*}, 36.6\left(\mathrm{CH}_{3}, \mathrm{MeEn}\right)^{*}, 52.9\left(\mathrm{CH}_{2}, \mathrm{MeEn}\right)^{*}$, $51.1\left(\mathrm{CH}_{2}, \mathrm{MeEn}\right)^{*}, 98.1(\mathrm{CH}, \mathrm{acac}), 114.4(\mathrm{CH}, \text { quin })^{*}, 115.7\left(\mathrm{C}_{\mathrm{q}}\right.$, quin $)^{*}, 117.0(\mathrm{CH}, \text { quin })^{*}, 121.6\left(\mathrm{C}_{\mathrm{q}}, \mathrm{ph}\right)^{*}, 122.0(\mathrm{CH}, \mathrm{ph}), 125.6$ $(\mathrm{CH}, \mathrm{ph}), 127.0(\mathrm{CH}, \mathrm{ph}) *, 127.5(\mathrm{CH}$, quin $), 129.6(\mathrm{CH}$, quin $)$, $131.0(\mathrm{CH}, \mathrm{ph}), 141.3\left(\mathrm{C}_{\mathrm{q}}, \mathrm{ph}\right), 142.1\left(\mathrm{C}_{\mathrm{q}} \text { quin }\right)^{*}, 148.5\left(\mathrm{C}_{\mathrm{q}} \text { quin }\right)^{*}$, $189.6\left(\mathrm{C}_{\mathrm{q}}, \mathrm{acac}\right), 190.1\left(\mathrm{C}_{\mathrm{q}}, \mathrm{acac}\right), 190.4\left(\mathrm{C}_{\mathrm{q}}, \mathrm{acac}\right)$.

Shifts of isomer D. ${ }^{1} \mathrm{H}$ NMR $\left(500.1 \mathrm{MHz}\right.$, DMSO- $\left.d_{6}\right): \delta 1.71(\mathrm{~s}, 3 \mathrm{H}$, $\mathrm{CH}_{3}$, acac), 1.88 (s, $3 \mathrm{H}, \mathrm{CH}_{3}$, acac), 2.19 (d, $3 \mathrm{H}, \mathrm{J}=6 \mathrm{~Hz}, \mathrm{CH}_{3}$, -MeEn), 2.58-3.04 (m, 3H, $\left.\mathrm{CH}_{2}, \mathrm{MeEn}\right), 3.68-3.92\left(\mathrm{~m}, 1 \mathrm{H}, \mathrm{CH}_{2}\right.$, MeEn), 4.75 (s, $1 \mathrm{H}, \mathrm{CH}, \mathrm{acac}), 5.67-5.75(\mathrm{~m}, 1 \mathrm{H}, \mathrm{CH}, \mathrm{acac}), 6.18[\mathrm{~m}$, $1 \mathrm{H}, \mathrm{NH}(\mathrm{en})$ ], 7.33-7.43 (m, 2H, CH, ph), 7.61-7.73 (m, 1H, CH, quin), 7.83-7.94 (m, 1H, CH, ph), 8.23-8.27 (m, 1H, CH, ph), 8.29$8.38[\mathrm{~m}, 1 \mathrm{H}, \mathrm{NH}(\mathrm{en})], 8.62-8.70(\mathrm{~m}, 1 \mathrm{H}, \mathrm{CH}$, quin), 8.70-8.74 (m, $1 \mathrm{H}, \mathrm{CH}$, quin), $10.21(\mathrm{~s}, 1 \mathrm{H}, \mathrm{NH}) .{ }^{13} \mathrm{C}$ NMR $(125.75 \mathrm{MHz}$, DMSO$\left.d_{6}\right): \delta 26.5\left(\mathrm{CH}_{3}, \mathrm{acac}\right)^{*}, 26.7\left(\mathrm{CH}_{3}, \mathrm{acac}\right)^{*}, 35.4\left(\mathrm{CH}_{3}, \mathrm{MeEn}\right), 53.5$ $\left(\mathrm{CH}_{2}, \mathrm{MeEn}\right)^{*}, 96.5(\mathrm{CH}, \mathrm{acac})^{*}, 98.6(\mathrm{CH}, \mathrm{acac})^{*}, 115.7\left(\mathrm{C}_{\mathrm{q}}\right.$, quin)*, $121.6\left(\mathrm{C}_{\mathrm{q}}, \mathrm{ph}\right) *, 122.1(\mathrm{CH}, \mathrm{ph}), 125.4(\mathrm{CH}, \mathrm{ph}), 127.0(\mathrm{CH}$, $\mathrm{ph})^{*}, 127.5(\mathrm{CH}$, quin $), 143.4\left(\mathrm{C}_{\mathrm{q}}, \text { quin }\right)^{*}, 189.3\left(\mathrm{C}_{\mathrm{q}}, \mathrm{acac}\right)^{*}, 189.5$ $\left(\mathrm{C}_{\mathrm{q}}, \mathrm{acac}\right)^{*}, 131.0(\mathrm{CH}, \mathrm{ph})$.

MS: calcd for $\left[\mathrm{C}_{27} \mathrm{H}_{32} \mathrm{BrCoN}_{5} \mathrm{O}_{4}\right]^{+}, 628.10$; found, 628.26. Anal. Calcd for $\mathrm{C}_{27} \mathrm{H}_{32} \mathrm{BrClCoN}_{5} \mathrm{O}_{4} \cdot 2 \mathrm{H}_{2} \mathrm{O}\left(M_{\mathrm{r}}=700.89 \mathrm{~g} / \mathrm{mol}\right): \mathrm{C}, 46.27$; H, 5.18; N, 9.99. Found: C, 46.24; H, 5.05; N, 9.77. *Detected only in 2D NMR.

Bis(3-methyl-2,4-pentanedionato) $N^{4}$-(3-Bromophenyl)- $N^{6}-[2-$ (methylamino)ethyl]quinazoline-4,6-diamine Cobalt(III) Chloride $\left[\mathrm{Co}(\text { Meacac })_{2} \mathrm{MeL}^{+}\right]$. $\mathrm{Na}\left[\mathrm{Co}(\mathrm{Meacac})_{2}\left(\mathrm{NO}_{2}\right)_{2}\right] \quad(85.6 \mathrm{mg}, 0.21$ mmol) was dissolved in $\mathrm{H}_{2} \mathrm{O}(1.6 \mathrm{~mL})$ and $\mathrm{MeOH}(1.2 \mathrm{~mL})$. MeL (100 mg, $0.23 \mathrm{mmol}$ ) was dissolved in $\mathrm{H}_{2} \mathrm{O}(1 \mathrm{~mL})$, neutralized with $\mathrm{NaOH}(1.8 \mathrm{~mL}, 0.25 \mathrm{M}$ in $\mathrm{MeOH})$, and then added with activated charcoal $(52.5 \mathrm{mg})$ to the cobalt precursor solution. The resulting mixture was stirred for $1 \mathrm{~h}$ at room temperature and filtered through Celite, which was washed with small amounts of $\mathrm{MeOH}$. Brine $(5.8 \mathrm{~mL})$ was added to the filtrate, and the resulting solution was extracted with dichloromethane $(3 \times 10 \mathrm{~mL})$. The organic phase was separated, dried with $\mathrm{Na}_{2} \mathrm{SO}_{4}$, and evaporated. The crude product (100 $\mathrm{mg}$ of a dark green solid) was purified by RP-HPLC $\left(\mathrm{H}_{2} \mathrm{O} / \mathrm{ACN}, 30-\right.$ $42 \% \mathrm{ACN}, 26 \mathrm{~min}$, without formic acid or TFA to avoid counter ion exchange). Yield: $37.6 \mathrm{mg}(24 \%)$. The ratio of the four isomers (A:B:C:D) was 1:0.34:0.23:0.19.

Shifts of the main isomer A. ${ }^{1} \mathrm{H}$ NMR $\left(500.1 \mathrm{MHz}\right.$, DMSO- $\left.d_{6}\right): \delta$ $1.00\left(\mathrm{~s}, 3 \mathrm{H}, \mathrm{CH}_{3}\right.$, Meacac), 1.57 (s, 3H, $\mathrm{CH}_{3}$, Meacac), $1.67-1.72(\mathrm{~m}$, $3 \mathrm{H}, \mathrm{CH}_{3}, \mathrm{MeEn}$ ), 1.90 (s, $3 \mathrm{H}, \mathrm{CH}_{3}$, Meacac), 2.08 (s, $3 \mathrm{H}, \mathrm{CH}_{3}$, 
Meacac), 2.11 (s, 3H, $\mathrm{CH}_{3}$, Meacac), 2.41 (s, 3H, $\mathrm{CH}_{3}$, Meacac), 2.58$3.00\left(\mathrm{~m}, 3 \mathrm{H}, \mathrm{CH}_{2}, \mathrm{MeEn}\right), 3.60-3.83\left(\mathrm{~m}, 1 \mathrm{H}, \mathrm{CH}_{2}, \mathrm{MeEn}\right), 6.61-6.76$ $[\mathrm{m}, 1 \mathrm{H}, \mathrm{NH}(\mathrm{en})], 7.31-7.44(\mathrm{~m}, 2 \mathrm{H}, \mathrm{CH}, \mathrm{ph}), 7.48(\mathrm{~d}, 1 \mathrm{H}, \mathrm{CH}, J=9$ $\mathrm{Hz}$, -quin), $7.55-7.71(\mathrm{~m}, 1 \mathrm{H}, \mathrm{CH}$, -quin $), 7.84(\mathrm{~d}, 1 \mathrm{H}, J=2.0 \mathrm{~Hz}, \mathrm{CH}$, ph), 8.06-8.17 [m, 3H, CH, quin $+\mathrm{ph}+\mathrm{NH}(\mathrm{en})], 8.60-8.72(\mathrm{~m}, 1 \mathrm{H}$, quin), 10.09 (s, $1 \mathrm{H}, \mathrm{NH}) .{ }^{13} \mathrm{C}$ NMR (125.75 MHz, DMSO- $\left.d_{6}\right): \delta 13.8$ $\left(\mathrm{CH}_{3}, \text { Meacac }\right)^{*}, 14.7\left(\mathrm{CH}_{3}\right.$, Meacac $), 26.1\left(\mathrm{CH}_{3}\right.$, Meacac $), 26.3$ $\left(\mathrm{CH}_{3}\right.$, Meacac $), 26.4\left(\mathrm{CH}_{3}\right.$, Meacac $), 26.6\left(\mathrm{CH}_{3}\right.$, Meacac $), 36.9\left(\mathrm{CH}_{3}\right.$, MeEn), $50.2\left(\mathrm{CH}_{2}, \mathrm{MeEn}\right), 53.0\left(\mathrm{CH}_{2}, \mathrm{MeEn}\right), 98.5\left(\mathrm{C}_{\mathrm{q}}\right.$, Meacac$)$, $101.2\left(\mathrm{C}_{\mathrm{q}}\right.$, Meacac), $113.7(\mathrm{CH}$, quin $) *, 121.1(\mathrm{CH}, \mathrm{ph}), 124.6(\mathrm{CH}$, ph), $126.4(\mathrm{CH}, \mathrm{ph}), 127.1(\mathrm{CH} \text {, quin })^{*}, 130.1(\mathrm{CH}, \text { quin })^{*}, 130.6$ ( $\mathrm{CH}, \mathrm{ph}), 140.9\left(\mathrm{C}_{\mathrm{q}}, \mathrm{ph}\right), 142.5\left(\mathrm{C}_{\mathrm{q}}\right.$, quin $), 156.9\left(\mathrm{C}_{\mathrm{q}}\right.$, quin), 187.0 $\left(\mathrm{C}_{\mathrm{q}}\right.$, Meacac $), 187.4\left(\mathrm{C}_{\mathrm{q}}\right.$, Meacac $), 187.5\left(\mathrm{CC}_{\mathrm{q}}\right.$, Meacac $), 188.2\left(\mathrm{C}_{\mathrm{q}}\right.$, Meacac).

Shifts of isomer B. ${ }^{1} \mathrm{H}$ NMR $\left(500.1 \mathrm{MHz}, \mathrm{DMSO}-d_{6}\right): \delta 1.67-1.72$ (m, 3H, $\mathrm{CH}_{3}$, Meacac), 1.79 (s, 3H, $\mathrm{CH}_{3}$, Meacac), 1.95 (s, 3H, $\mathrm{CH}_{3}$, Meacac), 2.04-2.14 (m, 6H, $\mathrm{CH}_{3}$, acac $\left.+\mathrm{MeEn}\right), 2.23\left(\mathrm{~s}, 3 \mathrm{H}, \mathrm{CH}_{3}\right.$, Meacac), 2.33 (s, 3H, $\mathrm{CH}_{3}$, Meacac), 2.58-3.00 (m, $\left.3 \mathrm{H}, \mathrm{CH}_{2}, \mathrm{MeEn}\right)$, 3.60-3.83 (m, $\left.1 \mathrm{H}, \mathrm{CH}_{2}, \mathrm{MeEn}\right), 5.85[\mathrm{~m}, 1 \mathrm{H}, \mathrm{NH}(\mathrm{en})], 7.13-7.23$ (m, $1 \mathrm{H}, \mathrm{CH}$, quin), 7.31-7.44 (m, 2H, CH, ph), 7.55-7.71 (m, $1 \mathrm{H}$, $\mathrm{CH}$, -quin), 7.87-8.03 [m, 2H, CH, ph + NH(en)], $8.24(\mathrm{~s}, 1 \mathrm{H}, \mathrm{CH}$, ph), 8.60-8.72 (m, $1 \mathrm{H}, \mathrm{CH}$, quin), $8.75(\mathrm{~s}, 1 \mathrm{H}, \mathrm{CH}$, quin), 10.23 (s, $1 \mathrm{H}, \mathrm{NH}) .{ }^{13} \mathrm{C}$ NMR $\left(125.75 \mathrm{MHz}\right.$, DMSO-d $\left.d_{6}\right): \delta 14.6\left(\mathrm{CH}_{3}\right.$, Meacac $)$, $14.7\left(\mathrm{CH}_{3}\right.$, Meacac $), 35.2\left(\mathrm{CH}_{3}, \mathrm{MeEn}\right), 26.4\left(\mathrm{CH}_{3}\right.$, Meacac$), 26.6$ $\left(\mathrm{CH}_{3}, \text { Meacac }\right)^{*}, 26.9\left(\mathrm{CH}_{3}\right.$, Meacac $), 26.1\left(\mathrm{CH}_{3}\right.$, Meacac $), 52.5$ $\left(\mathrm{CH}_{2}, \mathrm{MeEn}\right), 100.7$ (2C, $\mathrm{C}_{\mathrm{q}}$, Meacac), $121.1(\mathrm{CH}, \mathrm{ph}), 124.6(\mathrm{CH}$, ph)*, $126.4(\mathrm{CH}, \mathrm{ph}), 127.1(\mathrm{CH}, \text { quin })^{*}, 129.2(\mathrm{CH}$, quin $), 130.6$ $(\mathrm{CH}, \mathrm{ph}), 187.0\left(\mathrm{C}_{\mathrm{q}}\right.$, Meacac $), 187.3\left(\mathrm{C}_{\mathrm{q}}\right.$, Meacac $), 188.0\left(\mathrm{C}_{\mathrm{q}}\right.$, Meacac).

Shifts of isomer C. ${ }^{1} \mathrm{H}$ NMR (500.1 MHz, DMSO- $\left.d_{6}\right): \delta 1.75(\mathrm{~s}, 3 \mathrm{H}$, $\mathrm{CH}_{3}$, Meacac), 1.77-1.83 (m, 3H, $\mathrm{CH}_{3}, \mathrm{MeEn}$ ), 1.82 (s, $3 \mathrm{H}, \mathrm{CH}_{3}$, Meacac), 1.97 (s, 3H, $\mathrm{CH}_{3}$, Meacac), 2.04-2.14 (m, 3H, $\mathrm{CH}_{3}$, Meacac), 2.19 (s, 3H, $\mathrm{CH}_{3}$, Meacac), 2.37 (s, 3H, $\mathrm{CH}_{3}$, Meacac), 2.58$3.00\left(\mathrm{~m}, 3 \mathrm{H}, \mathrm{CH}_{2}, \mathrm{MeEn}\right), 3.60-3.83\left(\mathrm{~m}, 1 \mathrm{H}, \mathrm{CH}_{2}, \mathrm{MeEn}\right), 6.61-6.76$ $[\mathrm{m}, 1 \mathrm{H}, \mathrm{NH}(\mathrm{en})], 7.13-7.23(\mathrm{~m}, 1 \mathrm{H}, \mathrm{CH}$, quin), 7.31-7.44 (m, $2 \mathrm{H}$, $\mathrm{CH}, \mathrm{ph}), 7.55-7.71(\mathrm{~m}, 1 \mathrm{H}, \mathrm{CH}$, quin), 7.87-8.03 [m, 2H, CH, ph + $\mathrm{NH}(\mathrm{en})], 8.19(\mathrm{~s}, 1 \mathrm{H}, \mathrm{CH}, \mathrm{ph}), 8.60-8.72(\mathrm{~m}, 1 \mathrm{H}, \mathrm{CH}$, quin), $8.90(\mathrm{~s}$, $1 \mathrm{H}, \mathrm{CH}$, -quin), $10.28(\mathrm{~s}, 1 \mathrm{H}, \mathrm{NH}) .{ }^{13} \mathrm{C}$ NMR $(125.75 \mathrm{MHz}$, DMSO$\left.d_{6}\right): \delta 14.6\left(\mathrm{CH}_{3}\right.$, Meacac $), 14.7\left(\mathrm{CH}_{3}\right.$, Meacac $), 34.9\left(\mathrm{CH}_{3}, \mathrm{MeEn}\right)$, $26.2\left(\mathrm{CH}_{3}\right.$, Meacac $), 26.4\left(\mathrm{CH}_{3}\right.$, Meacac $) *, 52.7\left(\mathrm{CH}_{2}, \mathrm{MeEn}\right) *, 100.7$ (2C, $\mathrm{C}_{\mathrm{g}}$, Meacac), $121.1(\mathrm{CH}, \mathrm{ph}), 124.6(\mathrm{CH}, \mathrm{ph}) *, 126.4(\mathrm{CH}, \mathrm{ph}) *$, $127.1(\mathrm{CH}$, quin $) *$, $129.3(\mathrm{CH}$, quin $), 130.6(\mathrm{CH}, \mathrm{ph}), 187.2\left(\mathrm{C}_{\mathrm{q}}\right.$, Meacac)*, 187.5 (C, $\mathrm{C}_{\mathrm{q}}$ Meacac)*.

Shifts of isomer D. ${ }^{1} \mathrm{H}$ NMR $\left(500.1 \mathrm{MHz}\right.$, DMSO- $\left.d_{6}\right): \delta 1.76(\mathrm{~s}, 3 \mathrm{H}$, $\mathrm{CH}_{3}, \mathrm{MeEn}$ ), $1.77-1.83$ (m, 3H, $\mathrm{CH}_{3}$, Meacac), 1.99 (s, $3 \mathrm{H}, \mathrm{CH}_{3}$, Meacac), 2.04-2.14 (m, 3H, $\mathrm{CH}_{3}$, Meacac), $2.21-2.26\left(\mathrm{~m}, 3 \mathrm{H}, \mathrm{CH}_{3}\right.$, MeEn), 2.33 (s, 3H, $\mathrm{CH}_{3}$, Meacac), 2.58-3.00 (m, 3H, $\left.\mathrm{CH}_{2}, \mathrm{MeEn}\right)$, 3.60-3.83 (m, $\left.1 \mathrm{H}, \mathrm{CH}_{2}, \mathrm{MeEn}\right), 5.85$ [m, 1H, NH(en)], 7.31-7.44 (m, 2H, CH, ph), $7.47(\mathrm{~m}, 1 \mathrm{H}, \mathrm{CH}$, quin), 7.55-7.71 (m, 1H, CH, quin), $8.24(\mathrm{~s}, 1 \mathrm{H}, \mathrm{CH}, \mathrm{ph}), 8.06-8.17[\mathrm{~m}, 3 \mathrm{H}, \mathrm{CH}$, quin $+\mathrm{ph}+$ $\mathrm{NH}(\mathrm{en})], 8.60-8.72\left(\mathrm{~m}, 1 \mathrm{H}, \mathrm{CH}\right.$, quin), $10.14(\mathrm{~s}, 1 \mathrm{H}, \mathrm{NH}) .{ }^{13} \mathrm{C} \mathrm{NMR}$ $\left(125.75 \mathrm{MHz}, \mathrm{DMSO}-d_{6}\right): \delta 14.6\left(\mathrm{CH}_{3}, \mathrm{Meacac}\right)^{*}, 14.8\left(\mathrm{CH}_{3}\right.$, Meacac $)^{*}, 36.0\left(\mathrm{CH}_{3}, \mathrm{MeEn}\right) *, 26.4\left(\mathrm{CH}_{3}, \mathrm{Meacac}\right) *, 121.1(\mathrm{CH}, \mathrm{ph})$, $124.6(\mathrm{CH}, \mathrm{ph}) *, 126.4(\mathrm{CH}, \mathrm{ph}) *, 127.1(\mathrm{CH}$, quin $) *, 130.1(\mathrm{CH}$, quin $)^{*}, 130.6(\mathrm{CH}, \mathrm{ph}), 186.4\left(\mathrm{C}_{\mathrm{q}} \text {, acac }\right)^{*}, 187.7\left(\mathrm{C}_{\mathrm{q}}, \text { Meacac }\right)^{*}, 188.3$ $\left(\mathrm{C}_{\mathrm{q}}, \text { Meacac }\right)^{*}$.

MS: calcd for $\left[\mathrm{C}_{29} \mathrm{H}_{36} \mathrm{BrCoN}_{5} \mathrm{O}_{4}\right]^{+}, 656.13$; found, 656.13. Anal. Calcd for $\mathrm{C}_{29} \mathrm{H}_{36} \mathrm{BrClCoN}_{5} \mathrm{O}_{4} \cdot 2 \mathrm{H}_{2} \mathrm{O}\left(M_{\mathrm{r}}=728.95 \mathrm{~g} / \mathrm{mol}\right): \mathrm{C}$, 47.78; H, 5.53; N, 9.61. Found: C, 47.58; H, 5.40; N, 9.64. *Detected only in 2D NMR.

Bis(2,4-pentanedionato) (Phenyl-1,2-ethylenediamine) Cobalt(III) Hexafluorophosphate $\left[\mathrm{Co}(\text { acac })_{2} P h E n^{+}\right]$. $\mathrm{Na}\left[\mathrm{Co}(\mathrm{acac})_{2}\left(\mathrm{NO}_{2}\right)_{2}\right]$ (100 mg, $0.27 \mathrm{mmol}$ ) was dissolved in $\mathrm{H}_{2} \mathrm{O}(1.5 \mathrm{~mL})$ and $\mathrm{MeOH}(1$ $\mathrm{mL})$, and $N$-phenylethylenediamine $(36.9 \mu \mathrm{L}, 0.28 \mathrm{mmol})$ was added to the solution with a spatula tip of activated charcoal. The reaction mixture was stirred for $1 \mathrm{~h}$ at room temperature and filtered through Celite. $\mathrm{NH}_{4} \mathrm{PF}_{6}(152.4 \mathrm{mg}, 0.94 \mathrm{mmol})$ was added to the filtrate, and the solution was stored at $4{ }^{\circ} \mathrm{C}$ overnight. The formed grayish violet solid was filtered off and washed with ice-cold $\mathrm{H}_{2} \mathrm{O}$ and $\mathrm{Et}_{2} \mathrm{O}$. Yield: 45 $\mathrm{mg}(30 \%)$. The ratio of the two isomers was 1:0.81.
Shifts of the main isomer. ${ }^{1} \mathrm{H}$ NMR (500.1 MHz, DMSO- $\left.d_{6}\right): \delta 1.69$ (s, $3 \mathrm{H}, \mathrm{CH}_{3}$, acac), 2.00 (s, $3 \mathrm{H}, \mathrm{CH}_{3}$, acac), 2.10 (s, $3 \mathrm{H},-\mathrm{CH}_{3}$, acac), $2.18\left(\mathrm{~s}, 3 \mathrm{H}, \mathrm{CH}_{3}\right.$, acac), 2.52-2.91 (m, 3H, $\left.\mathrm{CH}_{2}, \mathrm{phEn}\right), 3.19-3.25(\mathrm{~m}$, $\left.1 \mathrm{H}, \mathrm{CH}_{2}, \mathrm{phEn}\right), 5.35\left(\mathrm{~s}, 1 \mathrm{H}, \mathrm{NH}_{2}\right), 5.56(\mathrm{~s}, 1 \mathrm{H}, \mathrm{CH}, \mathrm{acac}), 5.66(\mathrm{~s}, 1 \mathrm{H}$, $\mathrm{CH}, \mathrm{acac}), 5.88\left(\mathrm{~s}, 1 \mathrm{H}, \mathrm{NH}_{2}\right), 7.01(\mathrm{~d}, 1 \mathrm{H}, \mathrm{J}=2 \mathrm{~Hz}, \mathrm{CH}, \mathrm{ph}), 7.15$ (d, $2 \mathrm{H}, J=3 \mathrm{~Hz}, \mathrm{NH}), 7.19-7.35(\mathrm{~m}, 8 \mathrm{H}, \mathrm{CH}, \mathrm{ph})$.

Shifts of the minor isomer. ${ }^{1} \mathrm{H}$ NMR (500.1 MHz, DMSO- $\left.d_{6}\right): \delta 1.70$ (s, $3 \mathrm{H}, \mathrm{CH}_{3}$, acac), 1.95 (s, $3 \mathrm{H},-\mathrm{CH}_{3}$, acac), $1.98\left(\mathrm{~s}, 3 \mathrm{H}, \mathrm{CH}_{3}\right.$, acac), $2.19\left(\mathrm{~s}, 3 \mathrm{H}, \mathrm{CH}_{3}\right.$, acac), 2.52-2.91 (m, 3H, $\left.\mathrm{CH}_{2}, \mathrm{phEn}\right), 3.19-3.25$ (m, $\left.1 \mathrm{H}, \mathrm{CH}_{2}, \mathrm{phEn}\right), 4.91(\mathrm{~s}, 1 \mathrm{H}, \mathrm{CH}, \mathrm{acac}), 5.54\left(\mathrm{~s}, 1 \mathrm{H}, \mathrm{NH}_{2}\right), 5.64(\mathrm{~s}, 1 \mathrm{H}$, $\mathrm{CH}$, acac), $5.64\left(\mathrm{~s}, 1 \mathrm{H}, \mathrm{NH}_{2}\right), 7.01(\mathrm{~d}, 1 \mathrm{H}, J=2 \mathrm{~Hz}, \mathrm{CH}, \mathrm{ph}), 7.19-$ $7.35(\mathrm{~m}, 4 \mathrm{H}, \mathrm{CH}, \mathrm{ph}), 7.76(\mathrm{~d}, 2 \mathrm{H}, J=3 \mathrm{~Hz}, \mathrm{NH})$.

MS: calcd for $\left[\mathrm{C}_{18} \mathrm{H}_{26} \mathrm{CoN}_{2} \mathrm{O}_{4}\right]^{+}, 393.12$; found, 393.04. Anal. Calcd for $\mathrm{C}_{18} \mathrm{H}_{26} \mathrm{CoF}_{6} \mathrm{~N}_{2} \mathrm{O}_{4} \mathrm{P} \cdot 0.5 \mathrm{H}_{2} \mathrm{O}\left(M_{\mathrm{r}}=547.32 \mathrm{~g} / \mathrm{mol}\right): \mathrm{C}, 39.50 ; \mathrm{H}$, 4.97; N, 5.12. Found: C, 39.75; H, 4.82; N, 4.96.

Bis(3-methyl-2,4-pentanedionato) Ethylenediamine Cobalt(III) Hexafluorophosphate $\left[\mathrm{Co}(\text { Meacac })_{2} e^{+}\right]$. $\mathrm{Na}\left[\mathrm{Co}(\text { Meacac })_{2}\left(\mathrm{NO}_{2}\right)_{2}\right]$ ( $150 \mathrm{mg}, 0.37 \mathrm{mmol}$ ) was dissolved in $\mathrm{H}_{2} \mathrm{O}(2.25 \mathrm{~mL})$ and $\mathrm{MeOH}(1.5$ $\mathrm{mL})$, and ethylenediamine $(26.3 \mu \mathrm{L}, 0.39 \mathrm{mmol})$ was added with a spatula tip of activated charcoal. The reaction mixture was stirred for 1.5 $\mathrm{h}$ at room temperature and filtered through a syringe filter. $\mathrm{NH}_{4} \mathrm{PF}_{6}$ $(212 \mathrm{mg}, 1.3 \mathrm{mmol}$ ) was added to the filtrate, and the solution was stored at room temperature for $2 \mathrm{~h}$. Violet and orange crystals precipitated after a while. The solid was filtered off and washed with icecold $\mathrm{H}_{2} \mathrm{O}$ and $\mathrm{Et}_{2} \mathrm{O}$. Separation of the two compounds was carried out by dissolution in $\mathrm{MeOH}$. The insoluble orange crystals were filtered off, and the violet filtrate was evaporated and dried in vacuo. Yield: $30 \mathrm{mg}$ (16\%). ${ }^{1} \mathrm{H}$ NMR (500.1 MHz, DMSO- $\left.d_{6}\right): \delta 1.86\left(\mathrm{~s}, 6 \mathrm{H}, \mathrm{CH}_{3}\right.$, Meacac), 2.13 (s, 6H, $\mathrm{CH}_{3}$, Meacac), 2.15 (s, 6H, $\mathrm{CH}_{3}$, Meacac), 2.34 $\left(\mathrm{m}, 2 \mathrm{H}, \mathrm{CH}_{2}\right.$, en $), 2.45\left(\mathrm{~m}, 2 \mathrm{H}, \mathrm{CH}_{2}\right.$, en $), 4.78\left(\mathrm{~s}, 2 \mathrm{H}, \mathrm{NH}_{2}\right), 5.21(\mathrm{~s}$, $2 \mathrm{H}, \mathrm{NH}_{2}$ ). MS: calcd for $\left[\mathrm{C}_{18} \mathrm{H}_{26} \mathrm{CoN}_{2} \mathrm{O}_{4}\right]^{+}, 345.12$; found, 345.10. Anal. Calcd for $\mathrm{C}_{14} \mathrm{H}_{26} \mathrm{CoF}_{6} \mathrm{~N}_{2} \mathrm{O}_{4} \mathrm{P} \cdot 0.5 \mathrm{H}_{2} \mathrm{O}\left(M_{\mathrm{r}}=499.27 \mathrm{~g} / \mathrm{mol}\right): \mathrm{C}$, 33.68; H, 5.45; N, 5.61. Found: C, 33.85; H, 5.70; N, 5.39.

Bis(2,4-pentanedionato) (Methyl-1,2-ethanediamine) Cobalt(III) Hexafluorophosphate [Co(acac) $\left.{ }_{2} \mathrm{MeEn}^{+}\right] . \mathrm{Na}\left[\mathrm{Co}(\mathrm{acac})_{2}\left(\mathrm{NO}_{2}\right)_{2}\right]$ (500 mg, $1.34 \mathrm{mmol}$ ) was dissolved in $\mathrm{H}_{2} \mathrm{O}(7.5 \mathrm{~mL})$ and $\mathrm{MeOH}(5$ $\mathrm{mL})$, and $N$-methylethylenediamine $(123 \mu \mathrm{L}, 1.41 \mathrm{mmol})$ was added to the solution with a spatula tip of activated charcoal. The reaction mixture was stirred for $1.5 \mathrm{~h}$ at room temperature and filtered through Celite. $\mathrm{NH}_{4} \mathrm{PF}_{6}(763 \mathrm{mg}, 4.68 \mathrm{mmol})$ was added to the filtrate, and the solution was stored at $4{ }^{\circ} \mathrm{C}$ for 4 days. The formed violet crystals were filtered off and washed with ice-cold $\mathrm{H}_{2} \mathrm{O}$ and $\mathrm{Et}_{2} \mathrm{O}$. Yield: $252 \mathrm{mg}$ (39\%). ${ }^{1} \mathrm{H}$ NMR (500.1 MHz, DMSO- $\left.d_{6}\right): \delta 1.67(\mathrm{~d}, 3 \mathrm{H}, J=9 \mathrm{~Hz}$, $\left.\mathrm{CH}_{3}, \mathrm{MeEn}\right), 2.04$ (s, 3H, $\left.\mathrm{CH}_{3}, \mathrm{acac}\right), 2.06\left(\mathrm{~s}, 3 \mathrm{H}, \mathrm{CH}_{3}, \mathrm{acac}\right), 2.09$ (s, $\left.6 \mathrm{H}, \mathrm{CH}_{3}, \mathrm{acac}\right), 2.34-2.6\left(\mathrm{~m}, 4 \mathrm{H}, \mathrm{CH}_{2}, \mathrm{MeEn}\right), 5.27\left(\mathrm{~m}, 2 \mathrm{H}, \mathrm{NH}_{2}\right)$, $5.61(\mathrm{~s}, 1 \mathrm{H}, \mathrm{CH}, \mathrm{acac}), 5.63(\mathrm{~s}, 1 \mathrm{H}, \mathrm{CH}, \mathrm{acac}), 6.16(\mathrm{~s}, 1 \mathrm{H}, \mathrm{NH}) . \mathrm{MS}$ : calcd for $\left[\mathrm{C}_{13} \mathrm{H}_{24} \mathrm{CoN}_{2} \mathrm{O}_{4}\right]^{+}, 331.11$; found, 331.10. Anal. Calcd for $\mathrm{C}_{13} \mathrm{H}_{24} \mathrm{CoF}_{6} \mathrm{~N}_{2} \mathrm{O}_{4} \mathrm{P}\left(M_{\mathrm{r}}=476.24 \mathrm{~g} / \mathrm{mol}\right): \mathrm{C}, 32.79 ; \mathrm{H}, 5.08 ; \mathrm{N}, 5.88$. Found: C, 32.57; H, 5.11; N, 5.83.

Bis(3-methyl-2,4-pentanedionato) (Methyl-1,2-ethanediamine) Cobalt(III) Hexafluorophosphate [Co(Meacac) $\left.{ }_{2} \mathrm{MeEn}^{+}\right]$. Na[Co(Meacac) $\left.{ }_{2}\left(\mathrm{NO}_{2}\right)_{2}\right](100 \mathrm{mg}, 0.25 \mathrm{mmol})$ was dissolved in $\mathrm{H}_{2} \mathrm{O}(1.5$ $\mathrm{mL})$ and $\mathrm{MeOH}(1 \mathrm{~mL})$, and $N$-methylethylenediamine $(22.9 \mu \mathrm{L}$, $0.26 \mathrm{mmol}$ ) was added with a spatula tip of activated charcoal. The reaction mixture was stirred for $1.5 \mathrm{~h}$ at room temperature and filtered through a syringe filter. $\mathrm{NH}_{4} \mathrm{PF}_{6}(142 \mathrm{mg}, 0.87 \mathrm{mmol})$ was added to the filtrate, and the solution was stored at room temperature for $2 \mathrm{~h}$. The precipitated purple crystals were filtered off and washed with ice-cold $\mathrm{H}_{2} \mathrm{O}$ and $\mathrm{Et}_{2} \mathrm{O}$. Yield: $20 \mathrm{mg}(16 \%)$. The ratio of the two isomers was 1:0.30.

Shifts of the main isomer. ${ }^{1} \mathrm{H}$ NMR $\left(500.1 \mathrm{MHz}, \mathrm{DMSO}-d_{6}\right): \delta 1.60$ (d, $3 \mathrm{H}, J=8 \mathrm{~Hz}, \mathrm{CH}_{3}, \mathrm{MeEn}$ ), 1.84 (s, 3H, $\mathrm{CH}_{3}$, Meacac), 1.88 (s, $3 \mathrm{H}$, $\mathrm{CH}_{3}$, Meacac), 2.11 (s, 3H, $\mathrm{CH}_{3}$, Meacac), $2.16\left(\mathrm{~s}, 3 \mathrm{H}, \mathrm{CH}_{3}\right.$, Meacac), 2.18 (s, 3H, $\left.\mathrm{CH}_{3}, \mathrm{Meacac}\right), 2.21$ (s, 3H, $\mathrm{CH}_{3}$, Meacac), 2.23-2.40 (m, $\left.3 \mathrm{H}, \mathrm{CH}_{2}, \mathrm{MeEn}\right), 2.62\left(\mathrm{~s}, 1 \mathrm{H}, \mathrm{CH}_{2}, \mathrm{MeEn}\right), 4.97\left(\mathrm{~s}, 1 \mathrm{H}, \mathrm{NH}_{2}\right), 5.13(\mathrm{~s}$, $\left.1 \mathrm{H}, \mathrm{NH}_{2}\right), 5.96(\mathrm{~s}, 1 \mathrm{H}, \mathrm{NH})$.

Shifts of the minor isomer. ${ }^{1} \mathrm{H}$ NMR (500.1 MHz, DMSO- $\left.d_{6}\right): \delta 1.86$ (s, $\left.3 \mathrm{H}, \mathrm{CH}_{3}, \mathrm{MeEn}\right), 1.89$ (s, 3H, $\mathrm{CH}_{3}$, Meacac), 1.95 (d, $3 \mathrm{H}, J=11 \mathrm{~Hz}$, $\mathrm{CH}_{3}$, Meacac), 2.14 (s, $6 \mathrm{H}, \mathrm{CH}_{3}$, Meacac), 2.16 (s, 3H, $\mathrm{CH}_{3}$, Meacac), 
2.21 (s, 3H, $\mathrm{CH}_{3}$, Meacac), 2.23-2.40 (m, 3H, $\left.\mathrm{CH}_{2}, \mathrm{MeEn}\right), 2.62$ (s, $\left.1 \mathrm{H}, \mathrm{CH}_{2}, \mathrm{MeEn}\right), 4.81(\mathrm{~s}, 1 \mathrm{H}, \mathrm{NH}), 5.35\left(\mathrm{~m}, 2 \mathrm{H}, \mathrm{NH}_{2}\right)$.

MS: calcd for $\left[\mathrm{C}_{15} \mathrm{H}_{28} \mathrm{CoN}_{2} \mathrm{O}_{4}\right]^{+}$, 359.14; found, 359.12. Anal. Calcd for $\mathrm{C}_{15} \mathrm{H}_{28} \mathrm{CoF}_{6} \mathrm{~N}_{2} \mathrm{O}_{4} \mathrm{P} \cdot 0.5 \mathrm{H}_{2} \mathrm{O}\left(M_{\mathrm{r}}=522.31 \mathrm{~g} / \mathrm{mol}\right)$ : C, 35.1; H, 5.69; N, 5.46. Found: C, 35.21; H, 5.64; N, 5.16.

Kinase Screening. The EGFR (ErbB1) kinase-inhibitory potential of the novel ligand $\mathrm{MeL}$ in comparison to that of previously synthesized ligand $\mathbf{L}$ was evaluated using the Select Screen Biochemical Kinase Profiling Service at Life Technologies (ThermoFisher Scientific, Madison, WI). The test compounds were screened in a final DMSO concentration of $1 \%$ using the ZLYTE Assay in the presence of $10 \mu \mathrm{M}$ ATP.

Fluorescence Measurements. Fluorescence measurements were performed on a Horiba FluoroMax-4 spectrofluorometer, and the data were analyzed using FluorEssence version 3.5. The tested solutions were dissolved immediately prior to analysis in PBS ( $10 \mathrm{mM}, \mathrm{pH} 7.4)$ with a final concentration of $3 \times 10^{-5} \mathrm{M}$. Scans were run at room temperature with excitation and emission slit widths of $4 \mathrm{~nm}$. Emission scans were run from 375 to $600 \mathrm{~nm}$ using an excitation wavelength of $365 \mathrm{~nm}$. The 3D fluorescence spectra of $\mathrm{L}$ and $\mathrm{MeL}$ were determined at excitation wavelengths from 220 to $550 \mathrm{~nm}$, and emission was recorded within the range of $200-600 \mathrm{~nm}$.

Lipophilicity. Distribution coefficient $\left(D_{7.4}\right)$ values of the studied cobalt(III) compounds were determined by the traditional shake-flask method in an $n$-octanol/buffered aqueous solution at $\mathrm{pH} 7.40$ (PBS) and $25.0 \pm 0.2{ }^{\circ} \mathrm{C}$ as described previously. ${ }^{51}$ The complexes were dissolved in an $n$-octanol presaturated aqueous solution of the buffer at $\sim 100 \mu \mathrm{M}$. After phase separation, the UV-vis spectrum of the compound in the aqueous phase was compared to that of the original stock solution and the $D_{74}$ values of the compounds were calculated according to the following formula: [absorbance(original solution)/ absorbance(aqueous phase after separation) - 1].

Chemicals for Analytical Measurements. All solvents were of analytical grade and used without further purification. MeEn, PhEn, acac, Meacac, KH-phthalate, $\mathrm{K}_{3}\left[\mathrm{Fe}(\mathrm{III})(\mathrm{CN})_{6}\right], \mathrm{KCl}, \mathrm{NaCl}, \mathrm{HCl}$, $\mathrm{KOH}, \mathrm{AA}, \mathrm{GSH}$, and reduced $\mathrm{NADH}$ were products of Sigma-Aldrich. $\mathrm{CoCl}_{2} \cdot \mathrm{H}_{2} \mathrm{O}, \mathrm{NaH}_{2} \mathrm{PO}_{4}$, and $\mathrm{Na}_{2} \mathrm{HPO}_{4}$ were purchased from Reanal, and the exact concentration of the $\mathrm{CoCl}_{2}$ stock solution was determined by complexometry via its EDTA complex. Milli-Q water was used for sample preparation.

Cyclic Voltammetry. The compounds were dissolved in $10 \mathrm{mM}$ phosphate buffer ( $\mathrm{pH} 7.40$ ), with $0.1 \mathrm{M} \mathrm{KCl}$ as the supporting electrolyte, to obtain a final concentration of $1.5 \mathrm{mM}$. Electrochemical experiments were conducted on an EG\&G PARC 273A potentiostat/ galvanostat with scan rates of 30 and $1000 \mathrm{mV} / \mathrm{s}$ at room temperature. Argon was bubbled through the solution before every measurement to remove oxygen. A three-electrode configuration cell was used with a glassy carbon electrode as the working electrode, which was polished before every measurement. The reference electrode was $\mathrm{Ag} / \mathrm{AgCl} / \mathrm{KCl}$ $(3.5 \mathrm{M})$, and the auxiliary electrode was a platinum wire. Electrodes were conditioned regularly in $1 \mathrm{M} \mathrm{H}_{2} \mathrm{SO}_{4}$ for 5-10 cycles between voltage limits of -1.0 and $1.0 \mathrm{~V}$ at a scan rate of $100 \mathrm{mV} / \mathrm{s}$. The system was calibrated with $1.5 \mathrm{mM} \mathrm{K}_{3}\left[\mathrm{Fe}(\mathrm{CN})_{6}\right]$ for every experiment. Redox potentials measured relative to the $\mathrm{Ag} / \mathrm{AgCl} / \mathrm{KCl}(3.5 \mathrm{M})$ reference electrode were converted for potentials against $\mathrm{NHE}$ by the addition of $0.205 \mathrm{~V}$. Measurements were repeated at least three times, and the mean values were calculated.

Spectroscopic Studies of the Proton Dissociation and Redox Processes. Proton dissociation processes of PhEn were followed by UV-vis spectrophotometry and spectrofluorometry; samples were prepared in water containing 100 and $10 \mu \mathrm{M}$ ligand, respectively, and $0.1 \mathrm{M} \mathrm{KCl}$ at $25 \pm 0.2{ }^{\circ} \mathrm{C}$. The proton dissociation constants and the $\mathrm{UV}-\mathrm{vis}$ or fluorescence emission spectra of the individual species in the various protonation states were calculated by deconvolution of the spectra recorded in the $\mathrm{pH}$ range of $2.0-11.5$ with PSEQUAD. ${ }^{40}$ Reduction of the cobalt(III) compounds by AA, GSH, and NADH in aqueous solutions was followed for $24 \mathrm{~h}$ at $25.0^{\circ} \mathrm{C}$. All solutions were prepared under strictly oxygen-free conditions in an argon atmosphere. Batch samples contained $30 \mu \mathrm{M}$ cobalt(III) complex and 10 equiv of $\mathrm{AA}, \mathrm{GSH}$, or NADH in PBS buffer ( $\mathrm{pH} 7.40)$ and were used only once to record their UV-vis and fluorescence spectra. A Hewlett Packard 8452A diode array spectrophotometer was used in the interval of 200$800 \mathrm{~nm}$, and a Hitachi F-4500 spectrofluorometer was applied to record the emission spectra $\left(\lambda_{\mathrm{EX}}=290 \mathrm{~nm}\right.$ and $\lambda_{\mathrm{EM}}=310-450 \mathrm{~nm}$ in case of the titration of PhEn; $\lambda_{\mathrm{EX}}=370 \mathrm{~nm}$ and $\lambda_{\mathrm{EM}}=400-600 \mathrm{~nm}$ in the case of redox reactions).

pH-Potentiometric Measurements and Data Evaluation. For determination of the proton dissociation $\left(K_{\mathrm{a}}\right)$ and formation constants $(\beta) \mathrm{pH}$-potentiometric measurements were carried out at $25 \pm 0.1^{\circ} \mathrm{C}$ and an ionic strength $(I)$ of $0.10 \mathrm{M}(\mathrm{KCl})$ to keep the activity coefficients constant. A carbonate-free $\mathrm{KOH}$ solution $(0.10 \mathrm{M})$ was used for titrations. The exact concentrations of $\mathrm{HCl}$ and $\mathrm{KOH}$ were determined by $\mathrm{pH}$-potentiometric titrations. A Metrohm-combined electrode (type 6.0234.100) connected to an Orion 710A pH-meter and a computer-controlled Methrom 665 Dosimat buret (increment, 1 $\mu \mathrm{L}$; precision, $2 \mu \mathrm{L}$ ) were used for the $\mathrm{pH}$-potentiometric measurements. The electrode system was calibrated to the $\mathrm{pH}=-\log \left[\mathrm{H}^{+}\right]$scale by means of blank titrations (strong acid $\mathrm{HCl}$ vs strong base $\mathrm{KOH}$ ), as suggested by Irving et al. ${ }^{52}$ The determined average water ionization constant $\left(\mathrm{p} K_{\mathrm{w}}=13.76 \pm 0.01\right)$ corresponds well to the literature data. ${ }^{37}$ Titration points included in the calculations gave a reproducibility within $0.005 \mathrm{pH}$ unit. Titrations were performed in the $\mathrm{pH}$ range of $2.0-11.5$, and the initial volume of the samples was $10 \mathrm{~mL}$. Binary systems contained 1 or $2 \mathrm{mM}$ ligand, and metal:ligand ratios of 1:1, 1:2, $1: 3$, and 1:4 were used. In the ternary systems, the cobalt(II) concentration was $1 \mathrm{mM}$ and the two types of ligands (A, acac, and $\mathrm{B}, \mathrm{MeEn}$, or PhEn) were varied as follows: 1:1:1, 1:2:1, 1:1:2, and 1:2:2 $\mathrm{Co}(\mathrm{II}): \mathrm{A}: \mathrm{B}$. The samples were degassed by bubbling purified argon through them for $10 \mathrm{~min}$ prior to the measurements, and argon was also passed over the solutions during the titrations.

The stoichiometry of the complexes and overall stability constants were established by the computer program Hyperquad $2013 .{ }^{53}$ For the general equilibrium $\beta\left(\mathrm{M}_{p} \mathrm{~L}_{q} \mathrm{H}_{r}\right)$ is defined as

$$
p \mathrm{M}+q \mathrm{~L}+r \mathrm{H} \rightleftharpoons \mathrm{M}_{p} \mathrm{~L}_{q} \mathrm{H}_{r} \text { as } \beta\left(\mathrm{M}_{p} \mathrm{~L}_{q} \mathrm{H}_{r}\right)=\left[\mathrm{M}_{p} \mathrm{~L}_{q} \mathrm{H}_{r}\right] /[\mathrm{M}]^{p}[\mathrm{~L}]^{q}[\mathrm{H}]^{r}
$$

where $\mathrm{M}$ denotes the cobalt(II) ion and $\mathrm{L}$ the completely deprotonated ligand. The calculations were performed as reported in our previous work. $^{54}$

Serum Stability Measurements. For serum stability measurements, $135 \mu \mathrm{L}$ of FCS, buffered with $150 \mathrm{mM}$ phosphate $\left(\mathrm{Na}_{2} \mathrm{HPO}_{4} /\right.$ $\mathrm{NaH}_{2} \mathrm{PO}_{4}$ ) to maintain a $\mathrm{pH}$ value of 7.4 , was mixed with $15 \mu \mathrm{L}$ of a 500 $\mu \mathrm{M}$ stock solution of the respective complex in $50 \mathrm{mM}$ phosphate buffer to reach a final concentration of $50 \mu \mathrm{M}$. The samples were incubated at $37^{\circ} \mathrm{C}$. At different time points, to $20 \mu \mathrm{L}$ of serum was added $40 \mu \mathrm{L}$ of $\mathrm{ACN}$. After being vigorously shaked for $2 \mathrm{~min}$, the suspension was centrifuged at $6000 \mathrm{rpm}$ for $10 \mathrm{~min}$. The supernatant was taken up with a syringe and directly measured via HPLC-MS.

Biological Methods. Chemicals for Cell Culture Tests. All investigated drugs were dissolved in DMSO. These stock solutions $(10 \mathrm{mM})$ were further diluted into culture media containing $10 \%$ FCS at the indicated concentrations. The final DMSO concentrations were always less than $1 \%$. All other substances were purchased from SigmaAldrich (St. Louis, MO).

Cell Culture. Human cancer cell line A431 (epidermoid carcinoma, overexpressing EGFR/wt) was purchased from American Type Culture Collection (ATCC) (Rockville, MD). The cell line was grown, unless otherwise indicated, in humidified incubators $\left(37^{\circ} \mathrm{C}, 21 \% \mathrm{O}_{2}\right.$, and $5 \%$ $\mathrm{CO}_{2}$ ) in RPMI 1640 containing 10\% FCS (PAA, Linz, Austria). Under hypoxic conditions, plated and treated cells were incubated in humidified incubators (ProOx model C21 system von BioSpherix) with $0.1 \%, 1 \%$, or $5 \% \mathrm{CO}_{2}$ for the indicated period of time before analysis.

Cytotoxicity Assay. A431 cells were seeded $\left(3 \times 10^{3}\right.$ cells/well $)$ in 96-well plates, and after recovery for $24 \mathrm{~h}$, the dissolved drugs were added in increasing concentrations. After exposure to the drug for $72 \mathrm{~h}$, the proportion of viable cells was determined by the MTT assay following the manufacturer's recommendations (EZ4U, Biomedica, Vienna, Austria). Cytotoxicity was expressed as $\mathrm{IC}_{50}$ values calculated from full dose-response curves using GraphPad Prism. 
Western Blot Analysis. A431 cells were plated $\left(1 \times 10^{6}\right.$ cells $/ 60 \mathrm{~mm}$ dish) and allowed to recover for $24 \mathrm{~h}$, followed by serum starvation for $24 \mathrm{~h}$ (except the nonstarving control). Subsequently, the cells were treated with the drugs in different concentrations for $2 \mathrm{~h}$. In the final 10 min, EGF was added with a final concentration of $50 \mathrm{ng} / \mathrm{mL}$ to stimulate EGFR. Then, cells were harvested, and proteins were isolated, resolved by sodium dodecyl sulfate-polyacrylamide gel electrophoresis, and transferred onto a polyvinylidene difluoride membrane for Western blotting as previously described. ${ }^{17}$ The following antibodies were used: EGFR (8198), p-EGFR (Tyr1068) (3077), ERK 1/2 (9102), and p-ERK 1/2 (Thr202/Tyr204) (9101) (all monoclonal rabbit, Cell Signaling Technology, Beverly, MA) and $\beta$ actin (monoclonal mouse, Sigma). All primary antibodies were used in 1:1000 dilutions [in Tris-buffered saline containing 0.1\% Triton X-100 (TBST) with $3 \%$ bovine serum albumin (BSA)]. Additionally, horseradish peroxidase-labeled anti-mouse (7076) and anti-rabbit (7074) secondary antibodies were used at working dilutions of 1:10000 (in TBST with $1 \%$ BSA).

Fluorescence Microscopy. A431 cells were seeded $\left(5 \times 10^{5}\right.$ cells/ well) in six-well plates and allowed to recover overnight. Then, cells were treated with $10 \mu \mathrm{M}$ investigated drugs (diluted with $10 \%$ FCScontaining medium) for 6 or $24 \mathrm{~h}$. After incubation, the drug solutions were removed, and the cells were washed with PBS. Subsequently, microphotographs were taken using UV fluorescence microscopy (Nikon Eclipse Ti microscope with a DAPI filter and a high-pressure mercury lamp) and a $10 \times$ objective.

Flow Cytometry. For better quantification of the fluorescence intensity of released EGFR inhibitors, the previously microscoped cells were trypsinized, harvested, and centrifuged. The pellets were washed twice with PBS and further resuspended in Dulbecco's modified Eagle's medium (DMEM). Subsequently, the samples were measured on a LSR Fortessa flow cytometer (BD Biosciences, East Rutherford, NJ). The compound fluorescence was detected using $405 \mathrm{~nm}$ excitation and Pacific Blue $(450 / 50 \mathrm{~nm})$ band pass emission filters. Data were analyzed using the FACSDiva software and are depicted as the percent of fluorescence-positive cells and as the fluorescence intensity normalized to the autofluorescence.

\section{ASSOCIATED CONTENT}

\section{(s) Supporting Information}

The Supporting Information is available free of charge at https://pubs.acs.org/doi/10.1021/acs.inorgchem.0c03083.

NMR spectroscopic data of the cobalt complexes, concentration distribution diagram for cobalt(II)-acacMeEn, extracted ion mass chromatograms of the stability of the cobalt complexes, Western blot of MeL, and EGFR kinase screening of $\mathbf{L}$ and $\mathrm{MeL}$ (PDF)

\section{AUTHOR INFORMATION}

\section{Corresponding Author}

Christian R. Kowol - Institute of Inorganic Chemistry, Faculty of Chemistry, University of Vienna, 1090 Vienna, Austria; Research Cluster "Translational Cancer Therapy Research", University of Vienna and Medical University of Vienna, 1090 Vienna, Austria; (1) orcid.org/0000-0002-8311-1632; Email: christian.kowol@univie.ac.at

\section{Authors}

Marlene Mathuber - Institute of Inorganic Chemistry, Faculty of Chemistry, University of Vienna, 1090 Vienna, Austria

Hemma Schueffl - Institute of Cancer Research and Comprehensive Cancer Center, Medical University of Vienna, 1090 Vienna, Austria

Orsolya Dömötör - Department of Inorganic and Analytical Chemistry and MTA-SZTE Lendület Functional Metal
Complexes Research Group, University of Szeged, H-6720 Szeged, Hungary

Claudia Karnthaler - Institute of Inorganic Chemistry, Faculty of Chemistry, University of Vienna, 1090 Vienna, Austria

Eva A. Enyedy - Department of Inorganic and Analytical Chemistry and MTA-SZTE Lendület Functional Metal Complexes Research Group, University of Szeged, H-6720 Szeged, Hungary; ○ orcid.org/0000-0002-8058-8128

Petra Heffeter - Institute of Cancer Research and Comprehensive Cancer Center, Medical University of Vienna, 1090 Vienna, Austria; Research Cluster "Translational Cancer Therapy Research", University of Vienna and Medical University of Vienna, 1090 Vienna, Austria

Bernhard K. Keppler - Institute of Inorganic Chemistry, Faculty of Chemistry, University of Vienna, 1090 Vienna, Austria; Research Cluster "Translational Cancer Therapy Research", University of Vienna and Medical University of Vienna, 1090 Vienna, Austria

Complete contact information is available at: https://pubs.acs.org/10.1021/acs.inorgchem.0c03083

\section{Notes}

The authors declare no competing financial interest.

\section{ACKNOWLEDGMENTS}

This work was supported by the Austrian Science Fund (FWF) (Grant P28853, to C.R.K.), the National Research, Development and Innovation Office-NKFI through Projects FK124240 and PD131472, and FIKP Program TUDFO/47138-1/2019ITM. O.D. gratefully acknowledges the financial support from a J. Bolyai Research Fellowship. The authors thank Ing. Ingo Polivka for enthusiastic synthetic help and Ms. Vivien Pósa for performing some of the solution studies.

\section{REFERENCES}

(1) Chen, J.; Zeng, F.; Forrester, S. J.; Eguchi, S.; Zhang, M.-Z.; Harris, R. C. Expression and function of the epidermal growth factor receptor in physiology and disease. Physiol. Rev. 2016, 96 (3), 1025-1069.

(2) Hynes, N. E.; Lane, H. A. ERBB receptors and cancer: the complexity of targeted inhibitors. Nat. Rev. Cancer 2005, 5 (5), 341.

(3) Sigismund, S.; Avanzato, D.; Lanzetti, L. Emerging functions of the EGFR in cancer. Mol. Oncol. 2018, 12 (1), 3-20.

(4) Sharma, S. V.; Bell, D. W.; Settleman, J.; Haber, D. A. Epidermal growth factor receptor mutations in lung cancer. Nat. Rev. Cancer 2007, 7 (3), 169.

(5) Gazdar, A. Activating and resistance mutations of EGFR in nonsmall-cell lung cancer: role in clinical response to EGFR tyrosine kinase inhibitors. Oncogene 2009, 28 (1), S24-S31.

(6) Singh, M.; Jadhav, H. R. Targeting non-small cell lung cancer with small-molecule EGFR tyrosine kinase inhibitors. Drug Discovery Today 2018, 23 (3), 745-753.

(7) Bhullar, K. S.; Lagarón, N. O.; McGowan, E. M.; Parmar, I.; Jha, A.; Hubbard, B. P.; Rupasinghe, H. V. Kinase-targeted cancer therapies: progress, challenges and future directions. Mol. Cancer 2018, 17 (1), 48.

(8) Wang, Y.; Hu, G.-f.; Zhang, Q.-q.; Tang, N.; Guo, J.; Liu, L.-y.; Han, X.; Wang, X.; Wang, Z.-h. Efficacy and safety of gemcitabine plus erlotinib for locally advanced or metastatic pancreatic cancer: a systematic review and meta-analysis. Drug Des., Dev. Ther. 2016, 10, 1961.

(9) Aw, D. C. W.; Tan, E. H.; Chin, T. M.; Lim, H. L.; Lee, H. Y.; Soo, R. A. Management of epidermal growth factor receptor tyrosine kinase inhibitor-related cutaneous and gastrointestinal toxicities. Asia-Pac. J. Clin. Onco. 2018, 14 (1), 23-31. 
(10) Kiyohara, Y.; Yamazaki, N.; Kishi, A. Erlotinib-related skin toxicities: treatment strategies in patients with metastatic non-small cell lung cancer. J. Am. Acad. Dermatol. 2013, 69 (3), 463-472.

(11) Kudo, K.; Hotta, K.; Bessho, A.; Nogami, N.; Kozuki, T.; Kuyama, S.; Inoue, K.; Harita, S.; Okada, T.; Genba, K.; et al. Development of skin rash within the 1st week is a potential surrogate marker of therapeutic effect in afatinib monotherapy in patients with EGFR-mt non-small-cell lung cancer (NSCLC): Okayama Lung Cancer Study Group Experience. J. Clin. Oncol. 2015, 33, e19051.

(12) Kratz, F.; Müller, I. A.; Ryppa, C.; Warnecke, A. Prodrug strategies in anticancer chemotherapy. ChemMedChem 2008, 3 (1), $20-53$.

(13) Fouad, Y. A.; Aanei, C. Revisiting the hallmarks of cancer. Am. J. Cancer Res. 2017, 7 (5), 1016.

(14) Vaupel, P.; Mayer, A. Hypoxia in cancer: significance and impact on clinical outcome. Cancer Metastasis Rev. 2007, 26 (2), 225-239.

(15) Wilson, W. R.; Hay, M. P. Targeting hypoxia in cancer therapy. Nat. Rev. Cancer 2011, 11 (6), 393.

(16) Sharma, A.; Arambula, J. F.; Koo, S.; Kumar, R.; Singh, H.; Sessler, J. L.; Kim, J. S. Hypoxia-targeted drug delivery. Chem. Soc. Rev. 2019, 48 (3), 771-813.

(17) Karnthaler-Benbakka, C.; Groza, D.; Kryeziu, K.; Pichler, V.; Roller, A.; Berger, W.; Heffeter, P.; Kowol, C. R. Tumor-targeting of EGFR inhibitors by hypoxia-mediated activation. Angew. Chem., Int. Ed. 2014, 53 (47), 12930-12935.

(18) Karnthaler-Benbakka, C.; Groza, D.; Koblmüller, B.; Terenzi, A.; Holste, K.; Haider, M.; Baier, D.; Berger, W.; Heffeter, P.; Kowol, C. R.; Keppler, B. K. Targeting a Targeted Drug: An Approach Toward Hypoxia-Activatable Tyrosine Kinase Inhibitor Prodrugs. ChemMedChem 2016, 11 (21), 2410-2421.

(19) Patterson, A. V.; Silva, S.; Guise, C.; Bull, M.; Abbattista, M.; Hsu, A.; Sun, J. D.; Hart, C. P.; Pearce, T. E.; Smaill, J. B. TH-4000, a hypoxia-activated EGFR/Her2 inhibitor to treat EGFR-TKI resistant T790M-negative NSCLC. J. Clin. Oncol. 2015, 33, e13548.

(20) Bielec, B.; Schueffl, H.; Terenzi, A.; Berger, W.; Heffeter, P.; Keppler, B. K.; Kowol, C. R. Development and biological investigations of hypoxia-sensitive prodrugs of the tyrosine kinase inhibitor crizotinib. Bioorg. Chem. 2020, 99, 103778.

(21) Ware, D. C.; Palmer, B. D.; Wilson, W. R.; Denny, W. A. Hypoxia-selective antitumor agents. 7. Metal complexes of aliphatic mustards as a new class of hypoxia-selective cytotoxins. Synthesis and evaluation of cobalt (III) complexes of bidentate mustards. J. Med. Chem. 1993, 36 (13), 1839-1846.

(22) Jungwirth, U.; Kowol, C. R.; Keppler, B. K.; Hartinger, C. G.; Berger, W.; Heffeter, P. Anticancer activity of metal complexes: involvement of redox processes. Antioxid. Redox Signaling 2011, 15 (4), $1085-1127$.

(23) Heffern, M. C.; Yamamoto, N.; Holbrook, R. J.; Eckermann, A. L.; Meade, T. J. Cobalt derivatives as promising therapeutic agents. Curr. Opin. Chem. Biol. 2013, 17 (2), 189-196.

(24) Ware, D. C.; Siim, B.; Robinson, K.; Denny, W.; Brothers, P.; Clark, G. Synthesis and characterization of aziridine complexes of cobalt (III) and chromium (III) designed as hypoxia-selective cytotoxins. X-ray crystal structure of trans- $\left[\mathrm{Co}(\mathrm{Az})_{4}\left(\mathrm{NO}_{2}\right)_{2}\right] \mathrm{Br}$. $2 \mathrm{H}_{2} \mathrm{O} \cdot \mathrm{LiBr}$. Inorg. Chem. 1991, 30 (19), 3750-3757.

(25) Atkinson, I. M.; Searle, G. H.; Keene, F. R. Conformational analyses of the isomers of the systems $[\mathrm{Co}(\mathrm{men}) \mathrm{n}(\mathrm{en}) 3-\mathrm{n}]^{3+}(\mathrm{men}=$ $\mathrm{N}$-methylethane-1, 2-diamine, en= ethane-1, 2-diamine; $\mathrm{n}=1-3) . J$. Chem. Soc., Dalton Trans. 1991, 1, 45-51.

(26) Searle, G. H.; Keene, F. R. Cobalt (III) complexes with Nmethylethane-1, 2-diamine (meen). Synthesis and characterization of the isomers of $\left[\mathrm{Co}(\text { meen })_{3}\right]^{3+},\left[\mathrm{Co}(\text { meen })_{2}(\text { en })\right]^{3+}$ and $[\mathrm{Co}($ meen $)$ (en $\left.)_{2}\right]^{3+}$. Inorg. Chim. Acta 1989, 155 (1), 125-138.

(27) Chia, Y.; Tay, M. An insight into fluorescent transition metal complexes. Dalton Transactions 2014, 43 (35), 13159-13168.

(28) Lawaetz, A. J.; Stedmon, C. A. Fluorescence intensity calibration using the Raman scatter peak of water. Appl. Spectrosc. 2009, 63 (8), 936-940.
(29) Dömötör, O.; Pelivan, K.; Borics, A.; Keppler, B. K.; Kowol, C. R.; Enyedy, E. A. Comparative studies on the human serum albumin binding of the clinically approved EGFR inhibitors gefitinib, erlotinib, afatinib, osimertinib and the investigational inhibitor KP2187. J. Pharm. Biomed. Anal. 2018, 154, 321-331.

(30) Graf, N.; Lippard, S. J. Redox activation of metal-based prodrugs as a strategy for drug delivery. Adv. Drug Delivery Rev. 2012, 64 (11), 993-1004.

(31) Ware, D. C.; Palmer, H. R.; Pruijn, F. B.; Anderson, R. F.; Brothers, P. J.; Denny, W. A.; Wilson, W. R. Bis(dialkyl) dithiocarbamato cobalt (III) complexes of bidentate nitrogen mustards: synthesis, reduction chemistry and biological evaluation as hypoxia-selective cytotoxins. Anticancer Drug Des. 1998, 13 (2), 81103.

(32) Craig, P. R.; Brothers, P. J.; Clark, G. R.; Wilson, W. R.; Denny, W. A.; Ware, D. C. Anionic carbonato and oxalato cobalt (III) nitrogen mustard complexes. Dalton Trans. 2004, 4, 611-618.

(33) Failes, T. W.; Cullinane, C.; Diakos, C. I.; Yamamoto, N.; Lyons, J. G.; Hambley, T. W. Studies of a cobalt (III) complex of the MMP inhibitor marimastat: a potential hypoxia-activated prodrug. Chem. Eur. J. 2007, 13 (10), 2974-2982.

(34) Palmeira-Mello, M. V.; Caballero, A. B.; Ribeiro, J. M.; de SouzaFagundes, E. M.; Gamez, P.; Lanznaster, M. Evaluation of cobalt (III) complexes as potential hypoxia-responsive carriers of esculetin. J. Inorg. Biochem. 2020, 211, 111211 .

(35) Anderson, R.; Denny, W.; Ware, D.; Wilson, W. Pulse radiolysis studies on the hypoxia-selective toxicity of a colbalt-mustard complex. Br. J. Cancer 1996, 27, S48.

(36) Chang, J. Y.-C.; Lu, G.-L.; Stevenson, R. J.; Brothers, P. J.; Clark, G. R.; Botting, K. J.; Ferry, D. M.; Tercel, M.; Wilson, W. R.; Denny, W. A.; Ware, D. C. Cross-bridged cyclen or cyclam Co (III) complexes containing cytotoxic ligands as hypoxia-activated prodrugs. Inorg. Chem. 2013, 52 (13), 7688-7698.

(37) SCQuery; The IUPAC Stability Constants Database (ver. 5.5). Academic Software, 1993-2005.

(38) Enyedy, E. A.; Mészáros, J. P.; Dömötör, O.; Hackl, C. M.; Roller, A.; Keppler, B. K.; Kandioller, W. Comparative solution equilibrium studies on pentamethylcyclopentadienyl rhodium complexes of 2, 2'bipyridine and ethylenediamine and their interaction with human serum albumin. J. Inorg. Biochem. 2015, 152, 93-103.

(39) Griesser, R.; Sigel, H. Ternary complexes in solution. XI. Complex formation between the cobalt (II)-, nickel (II)-, copper (II)-, and zinc (II)-2, 2'-bipyridyl 1:1 complexes and ethylenediamine, glycinate, or pyrocatecholate. Inorg. Chem. 1971, 10 (10), 2229-2232.

(40) Zékány, L.; Nagypál, I.; Leggett, D. Computational methods for the determination of stability constants; Plenum Press: New York, 1985.

(41) Schafer, F. Q.; Buettner, G. R. Redox environment of the cell as viewed through the redox state of the glutathione disulfide/glutathione couple. Free Radical Biol. Med. 2001, 30 (11), 1191-1212.

(42) Fasman, G., Ed. CRC Handbook of Biochemistry and Molecular Biology; CRC Press: Cleveland, OH, 1976; p 122.

(43) Matsui, T.; Kitagawa, Y.; Okumura, M.; Shigeta, Y. Accurate standard hydrogen electrode potential and applications to the redox potentials of vitamin C and NAD/NADH. J. Phys. Chem. A 2015, 119 (2), 369-376.

(44) Lovander, M. D.; Lyon, J. D.; Parr, D. L.; Wang, J.; Parke, B.; Leddy, J. Critical Review-Electrochemical Properties of 13 Vitamins: A Critical Review and Assessment. J. Electrochem. Soc. 2018, 165 (2), G18-G49.

(45) Yu, Q.; Heikal, A. A. Two-photon autofluorescence dynamics imaging reveals sensitivity of intracellular NADH concentration and conformation to cell physiology at the single-cell level. J. Photochem. Photobiol., B 2009, 95 (1), 46-57.

(46) Meister, A. Glutathione metabolism and its selective modification. J. Biol. Chem. 1988, 263 (33), 17205-17208.

(47) Hunter, F. W.; Young, R. J.; Shalev, Z.; Vellanki, R. N.; Wang, J.; Gu, Y.; Joshi, N.; Sreebhavan, S.; Weinreb, I.; Goldstein, D. P.; et al. Identification of $\mathrm{P} 450$ oxidoreductase as a major determinant of 
sensitivity to hypoxia-activated prodrugs. Cancer Res. 2015, 75 (19), 4211-4223.

(48) Ahn, G.-O.; Botting, K. J.; Patterson, A. V.; Ware, D. C.; Tercel, M.; Wilson, W. R. Radiolytic and cellular reduction of a novel hypoxiaactivated cobalt (III) prodrug of a chloromethylbenzindoline DNA minor groove alkylator. Biochem. Pharmacol. 2006, 71 (12), 16831694.

(49) Dai, Z.-J.; Gao, J.; Ma, X.-B.; Yan, K.; Liu, X.-X.; Kang, H.-F.; Ji, Z.-Z.; Guan, H.-T.; Wang, X.-J. Up-regulation of hypoxia inducible factor- $1 \alpha$ by cobalt chloride correlates with proliferation and apoptosis in PC-2 cells. J. Exp. Clin. Cancer Res. 2012, 31 (1), 28.

(50) Stary, J.; Liljenzin, J. Critical evaluation of equilibrium constants involving acetylacetone and its metal chelates. Pure Appl. Chem. 1982, 54 (12), 2557-2592.

(51) Enyedy, É. A.; Hollender, D.; Kiss, T. Lipophilicity of kinetically labile metal complexes through the example of antidiabetic $\mathrm{Zn}$ (II) and VO (IV) compounds. J. Pharm. Biomed. Anal. 2011, 54 (5), 10731081.

(52) Irving, H.; Miles, M.; Pettit, L. A study of some problems in determining the stoicheiometric proton dissociation constants of complexes by potentiometric titrations using a glass electrode. Anal. Chim. Acta 1967, 38, 475-488.

(53) Gans, P; Sabatini, A; Vacca, A A. Vacca, Investigation of equilibria in solution. Determination of equilibrium constants with the HYPERQUAD suite of programs. Talanta 1996, 43, 1739-1753.

(54) Poljarevic, J. M.; Tamas Gal, G.; May, N. V.; Spengler, G.; Domotor, O.; Savic, A. R.; Grguric-Sipka, S.; Enyedy, E. A. Comparative solution equilibrium and structural studies of half-sandwich ruthenium(II)(eta(6)-toluene) complexes of picolinate derivatives. J. Inorg. Biochem. 2018, 181, 74-85. 